\title{
Interferons as Hormones of Pregnancy*
}

\author{
R. MICHAEL ROBERTS, JAMES C. CROSS, AND DOUGLAS W. LEAMAN
}

Departments of Animal Sciences (R.M.R., D.W.L.) and Biochemistry (R.M.R.), University of Missouri, Columbia, Missouri 65211; and Laboratory of Radiobiology and Environmental Health (J.C.C.), University of California, San Francisco, California 94143-0750

I. Introduction

II. The Trophoblast Proteins, oTP-1 and bTP-1, Are Hormones of Pregnancy and Related Structurally to Type I IFN

A. Preimplantation conceptus development and maternal recognition of pregnancy

B. Antiluteolysins of sheep and cattle

C. Molecular cloning and identification of trophoblast proteins as interferons

III. Bioactivities of the Trophoblast IFN

A. Antiviral, antiproliferative, and immunomodulatory properties

B. Comparative effects of IFN $\tau$ and $\mathrm{IFN} \alpha$ on reproductive parameters

C. Interaction of $\mathrm{IFN} \tau$ with type I receptors

D. Second messenger systems for the IFN $\tau$

IV. The Expression of IFN During Pregnancy

A. Are Type I IFN expressed universally by embryonic and placental tissues?

B. Maturation of the IFN system during embryonic development

C. General features of transcriptional regulation of IFN $\alpha$, $-\beta$ and $-\omega$

D. IFN $\tau$ genes are regulated in a cell- and developmentally specific manner

1. Trophoblast cell expression

2. Temporal pattern of expression

E. Features of IFN $\tau$ gene promoters

1. The promoter dictates cell specificity

2. The trophoblast IFN promoter is functionally distinct from other type I IFN

$\mathrm{V}$. The Uniqueness of the IFN $\tau$

A. Evolution of the IFN $\tau$ genes and their restricted distribution in mammals

B. The IFN $\tau$ are a structurally distinct type I IFN subtype

C. Do the IFN $\tau$ have unique biological properties?

\section{Introduction}

$\mathrm{A}^{\mathrm{a}+x^{2}}$ BOUT 5 yr ago it was discovered that a protein which was secreted in quantity by preimplantation

Address requests for reprints to: R. Michael Roberts, Ph.D Department of Animal Sciences, College of Agriculture, University of Missouri, 158 Animal Sciences Center, Columbia, Missouri 65211.

* Supported by NIH Grant 21896. This paper is a contribution from the Missouri Agricultural Experiment Station, Journal Series Number 11,660 . sheep conceptuses and implicated in preventing luteolysis during the second and third weeks of pregnancy was, in fact, structurally related to type I interferons (IFN), proteins best known for their antiviral and immunomodulatory activities. This discovery attracted considerable attention because it revealed a new and completely unsuspected role for a cytokine as a reproductive hormone. Several reviews have been published on various aspects of this topic (1-10). In the more comprehensive updated article that follows, we describe how IFN came to be implicated as antiluteolytic agents in domestic ruminant species, the properties of these IFN, and some of the unusual features pertaining to their expression and transcriptional regulation. We address the questions as to whether these IFN have any unique biological and structural properties, as to how they evolved, and as to whether type I IFN in general might have a universal role in mammalian pregnancy.

A few terms are used throughout this review with which the reader may not be entirely familiar. For example, we prefer to use conceptus rather than embryo, because the former term encompasses the trophoblast and fetal membranes, as well as the embryo proper. In later pregnancy, fetal-placental unit can be appropriately substituted for conceptus. From Section III onward we have also chosen to name the IFN produced by the preimplantation ruminant conceptus as IFN $\tau$ to distinguish it from the related IFN $\alpha,-\beta$, and $-\omega$. This abbreviation became necessary in order to avoid the continued use of older terms such as trophoblast proteins (including oTP-1 and bTP-1), trophoblastin, embryonic interferons, IFN $\alpha_{\text {II }}$, and IFN $\alpha 2$ which either have value only in a historical context or else are inappropriate or incorrect. The classification, although not yet sanctioned by any official committee on IFN nomenclature, is most likely justifiable in view of the clear-cut differences between these IFN and the other type I IFN subfamilies (see Section V.B). 


\section{The Trophoblast Proteins, oTP-1 and bTP-1, Are Hormones of Pregnancy and Related Structurally to Type I IFN}

\section{A. Preimplantation conceptus development and maternal recognition of pregnancy}

After the egg has been fertilized, the conceptus of a eutherian mammal follows a programmed path of cell cleavage and development until the blastocyst is formed (11). In some species, including mouse and human, the hatched blastocyst immediately attaches to the uterine wall, trophoblast outgrowth begins, and implantation is initiated. In others, e.g. rabbit, the blastocyst enlarges considerably before the trophoblast begins to intrude through the uterine epithelium. Preimplantation development of the conceptus is even more extensive within the hoofed mammals, which include the domestic ruminants, e.g. cattle, goats, and sheep, and many monogastric species such as pigs and horses. In all these animals, the blastocyst continues to expand after hatching until it reaches a diameter of several millimeters. At about day $12-13$ in sheep or day $14-15$ in cattle, this spherical structure starts to elongate until it reaches a length of $15 \mathrm{~cm}$ or more, 3 days later, a process which places the trophoblast in direct apposition with much of the luminal terine epithelium. During this remarkable phase of slongation, which is largely attributable to growth of the rophoblast, the outer cell layer, or trophectoderm, evenzually begins to attach to the enclosing uterine epitheium, and implantation is initiated at specific sites (1214), the caruncles, on the uterine wall where trophoblast jinucleate cells become concentrated (15). The regions of fused trophoblast and maternal caruncular tissue ulimately develop into prominent, well vascularized strucures known as placentomes, which are the sites of prinary gas exchange and nutrient transport after the first 3 to 4 weeks of pregnancy. They are also sites at which rophoblast binucleate cells release placental hormones, ;uch as the placental lactogens, toward the maternal rasculature (16).

In species where implantation occurs relatively late in levelopment, the early conceptus is clearly capable of communicating" with the mother well before erosion of he uterine epithelium has become apparent and without he trophoblast having direct access to the maternal asculature (3). Therefore, the molecules involved in ommunication must either diffuse or be transported cross the intact epithelium to enter the maternal cirulation. Alternatively, they must elicit their effect loally, with the endometrium acting as a transducer of vhatever primary response the conceptus initiates.

The term maternal recognition of pregnancy has been ssed in its broadest sense to describe how the mother esponds to the presence of a conceptus within her re- productive tract and, particularly, how such events allow the pregnancy to advance successfully (17). One important outcome of such conceptus-maternal interaction in most mammals is extension of the functional lifespan of the corpus luteum (CL), an event that ensures continued production of uterotrophic steroid hormones, and progesterone in particular. This process creates a uterine environment conducive for continued development of the conceptus. Failure of the conceptus to signal its presence within the appropriate timeframe results in loss of the pregnancy. Rates of embryonic mortality resulting from such miscommunication between the mother and conceptus at the time of maternal recognition of pregnancy are believed to be high in farm animal species $(18,19)$, and such losses have considerable economic implications.

The timing of maternal recognition of pregnancy varies widely among different mammals, and the methods utilized for maintaining a functional CL of pregnancy also differ from species to species. In primates, the CL is "rescued" through the actions of a luteotrophic hormone, chorionic gonadotropin (CG), released by the trophoblast as it implants (20). Production of CG is readily detectable in maternal circulation by day 8-11 of pregnancy in humans when the maternal blood supply comes in contact with the embryonic trophectoderm (21). CG acts directly on the CL and is probably essential to sustain luteal cell function for the first month of pregnancy, by which time placental progesterone production begins to be sufficient to maintain the pregnancy (22). In the absence of a developing conceptus, the CL undergoes a spontaneous structural regression through currently unknown mechanisms.

There is little evidence for a placental gonadotropin in domestic ungulates such as pigs, sheep, and cattle, at least in the early stages of pregnancy. In these animals, the initial role of the conceptus appears to be in the prevention of luteolysis rather than in luteal maintenance. Luteal regression does not occur spontaneously in cyclic females, but requires the episodic release of prostaglandin $\mathrm{F}_{2 \alpha}(\mathrm{PGF})$ originating from the uterine endometrium (23-26). The hormonal regulation of PGF production during the nonfertile cycle in ruminants has been extensively reviewed and likely involves control by oxytocin originating from the posterior pituitary and/or the CL $(26,27)$. PGF released by the endometrium travels by a counter-current mechanism via the uteroovarian vasculature to the ovary where it interacts with specific cell surface receptors to promote rapid regression of the CL during the late luteal phase of the estrous cycle.

\section{B. Antiluteolysins of sheep and cattle}

In domestic ruminants, luteal regression is thought to be prevented in early pregnancy by a conceptus-mediated 
suppression of episodic PGF production or release (2427). The sequence of events leading up to the identification and purification of the primary ovine and bovine conceptus products involved with this process has been reviewed extensively (1-10) and will not be discussed in detail here. However, several significant contributions to their identification are worthy of mention. Early investigations indicated that this conceptus signal was proteinaceous, based on its heat lability and susceptibility to protease inactivation. It was also shown to be secreted transiently by the sheep conceptus between days 12 and 21 of pregnancy, and had to be recognized by the mother before day 13 to prevent resumption of a normal luteal cycle.

In 1982 Godkin et al. (28) described the purification of a low molecular weight protein released into culture medium by day $13-21$ ovine conceptuses. This secretory protein, eventually designated ovine trophoblast protein1 (oTP-1) (29), which in retrospect was probably identical to trophoblastin, a protein partially characterized 3 yr earlier by Martal et al. (30) from conceptus homogenates, consisted of several isoforms with mol wt of about 18,000 , and isoelectric points ranging from 5.3 to 5.7 (28, 29). Shortly thereafter, it was demonstrated that bovine conceptuses produced a similar complex of proteins [bovine trophoblast protein-1 (bTP-1)] (31) that cross-reacted with oTP-1 antiserum (32), although each component was of slightly higher mol wt $(22,000$ to 24,000$)$. The differences in size between oTP-1 and bTP-1 variants were later attributed to the presence of carbohydrate on the bovine, but not the ovine TP-1 $(33,34)$.

Infusion of oTP-1 into the uteri of nonpregnant ewes resulted in an extension of luteal lifespan comparable to that observed with total conceptus secretory products $(35,36)$ and led to a blunting of the pulsatile release of PGF from the uterus (37). Furthermore, infusion of conceptus secretory products from which oTP-1 had been removed by immunoadsorption failed to increase the interestrous interval (36). These observations, plus the fact that oTP-1 production was limited to the critical window of maternal recognition of pregnancy, strongly implicated oTP-1 as the ovine antiluteolysin (and by analogy, bTP-1 as the bovine antiluteolysin). More recently, the goat conceptus has also been shown to produce an abundant caprine TP-1 protein (cTP-1) $(38,39)$.

Unlike CG of primates, oTP-1 does not enter the maternal circulation in appreciable quantity (Section $I V . D)$ and has no direct luteotrophic effects (29). Instead, it acts locally upon the uterus $(24,25)$. Interestingly in sheep, basal PGF production is not eliminated, and circulating levels of the PGF metabolite, 15-keto-13,14dihydro-PGF, can be higher in pregnant ewes than in cyclic ewes (40-42). However, in pregnant animals, pulses of PGF are diminished, and the CL remains functional for much of the pregnancy. The exact mechanisms whereby the TP-1 of sheep and cattle modulate PGF production or release are not yet known, although several possible models will be discussed later in this review (Section III.B). Whether the conceptus produces additional factors that cause the CL to remain refractory to the tonic release of PGF by the uterus during pregnancy is also currently unknown. Recent data have suggested that the peri-implantation ovine conceptus secretes a protein that protects luteal cells from the luteolytic action of PGF, but the identity and mode of action of this product remain to be elucidated (43). In addition, low molecular weight metabolites, such as PGE, released by the conceptus, and known to be weakly luteotrophic, may play some role in luteal maintenance (44). Clearly, factors other than the TP-1 must be involved with luteal maintenance later in pregnancy since administration of oTP-1 or bTP-1 extends luteal lifespan for only days to a few weeks $(35,36)$, whereas the CL normally persists throughout pregnancy.

\section{Molecular cloning and identification of trophoblast proteins as interferons}

The identification of oTP-1 and bTP-1 as type I IFN was unsuspected and was the result of molecular cloning of cDNA $(45,46)$ and protein sequencing $(47,48)$ procedures. The discovery revealed a novel role for IFN in the normal physiology of early embryonic development. As will be discussed throughout the remainder of this manuscript, these trophoblast IFN (IFN $\tau$ ) possess a number of unique features which not only suit them well for their role in the establishment of pregnancy but also distinguish them from other well characterized type I IFN. Since those original reports, a large number of additional cDNA sequences have been published (4954). All of these cDNA have certain common features: they are about 1 kilobase in length and possess 585 base pairs (bp) open reading frames that code for 195 amino acid polypeptides. Ultimately these isoforms will have to be classified as ovIFN- $\tau 1$, ovIFN- $\tau 2$, etc.

IFN were so named because they could confer resistance to cells to subsequent viral infection $(55,56)$. Unfortunately, such a functional definition has tended to underplay the involvement of IFN in modulating processes such as cellular differentiation, proliferation, and immune function (56-58) as well as in reproduction (59). It also led to the classifying together of quite different molecules simply because they displayed similar antiviral activity. Subsequently it has become clear that there are at least two different types of IFN, types I and II (Table 1) which bear little structural resemblance to each other.

In those mammalian species where it has been studied, type II IFN is represented by a single gene and is better 
known as IFN $\gamma$ (56). Although often considered to be primarily a product of $\mathrm{T}$ cells and to function in activating macrophage, IFN $\gamma$ (or immune IFN) is released by a variety of cell types, including porcine trophoblast (60, 61) and has broad pleiotropic effects (62). There is no evidence, however, that it functions as an antiluteolysin in pigs (see Section IV.B).

Type I IFN, by contrast, consists of at least three distinct subtypes ( $\alpha-, \beta-$, and $\omega$-) (Table 1$)$. Although each of these possesses similar biological properties, presumably due to their binding to a common receptor (Section III.C), each subtype differs considerably in amino acid sequence and serological properties (56, 63$66)$. Each subtype can be encoded by multiple genes, and the different gene products within a subtype such as the IFN $\alpha$, for example, can themselves differ significantly in sequence and most probably in biological potency (56). In cattle there are at least 15 known $\alpha$-genes (63), 9-11 $\beta$-genes (67), and at least $15-20$ genes related to the IFN $\omega(63)$.

The various boIFN $\tau$ gene products of cattle have less than $30 \%$ sequence identity to IFN $\beta$ and only about $50 \%$ identity to known bovine IFN $\alpha$ (46). The greatest similarity $(\sim 70 \%)$ is to IFN $\omega$ (previously known as IFN $\alpha_{\text {II }}$ ). However, boIFN $\tau$ and ovIFN $\tau$ resemble each other in both amino acid and nucleotide gene sequence more than they do the IFN $\omega$ within their own species. Thus, there are compelling reasons to consider IFN $\tau$ as a distinct structural subtype (see Section V.B).

The sequence of one isoform of ovIFN $\tau$, which was deduced from a complementary DNA, is shown in Fig. 1A. As in all $\operatorname{IFN} \alpha(56,65)$ and in the 172 -amino acid IFN $\omega$ (68), the $\mathrm{NH}_{2}$-terminal residue is a highly conserved cysteine that is probably in an intramolecular disulfide linkage with cys ${ }^{99}$ (69). A second disulfide most likely links cys ${ }^{29}$ and cys ${ }^{139}$. The latter pair of cysteines are found on all type I IFN, and the intact disulfide is essential for biological activity. In addition to these four cysteines, there are 16 additional amino acids that are highly conserved across all known IFN $\alpha,-\beta$, and $-\omega$ (70,

TABLE 1. Description of IFN subtypes

\begin{tabular}{lll}
\hline & \multicolumn{1}{c}{ Type I } & \multicolumn{1}{c}{ Type II } \\
\hline Acid stable: & Yes & No \\
Inducer: & Virus & T cell activation \\
Cell of origin: & Several & T cell ${ }^{a}$ \\
Subtypes: & Alpha (multiple) & Gamma (single) \\
& Beta (single) & \\
& Omega (multiple) & \\
Genes: & Intronless & 3 introns \\
Chromosomal location & Clustered on chromo- & Chromo- \\
(human): & some 9 & some 12 \\
\hline
\end{tabular}

${ }^{a}$ Also produced by pig trophoblast.

${ }^{b}$ Multiple genes in ungulates.
71). Significantly, all 20 of these amino acids are placed identically in most IFN $\tau$ (Fig. 1A and 1B).

As noted earlier, it is curious that there is so much diversity in amino acid sequence among the type I IFN. IFN $\alpha$ isoforms within a single species can vary by as much as $20 \%$ or more in overall sequence. Despite these apparent differences, however, hydrophilicity-hydrophobicity plots of the primary structures of any chosen type I IFN are barely distinguishable $(3,72)$. All seem to possess quite similar predicted secondary structures $(3$, 71-73). It is unfortunate that at the time of writing, precise three-dimensional conformations of IFN $\alpha$ and $\beta$ are not available. However, a representative murine IFN $\beta$ has been crystallized $(74,75)$, and preliminary data on its structure have been published as an abstract (75). Theoretical conformation analyses suggest that all type I IFN fold similarly and probably consist of five $\alpha$-helices (A through E; Fig. 1B) arranged in an antiparallel manner and connected by loop regions (71-73). Although the precise packing topology of the helices is unclear, the five-helix structure shown in Fig. 1B is probably roughly correct and can provide a useful working model as to how type I IFN interact with their common receptor (Section III.C). The positioning of the poorly conserved carboxyl "tail," which is six to seven residues longer in IFN $\omega$ and IFN $\tau$ than in IFN $\alpha$ or $-\beta$, is particularly difficult to predict, however, and is shown in Fig. 1B as a projection that extends downward from helix E, although it may fold back across the molecule.

The ovIFN $\tau$ molecule in Fig. 1 possesses a potential site for $\mathrm{N}$-glycosylation on $\mathrm{Asn}^{78}$. However, not all predicted ovIFN $\tau$ sequences have this motif (51), and there is no biochemical evidence that any of the isoforms is a glycoprotein $(28,32-34)$. On the other hand, boIFN $\tau$ (33, 34 ) and some forms of caprine TP-1 (39) are N-glycosylated, presumably on $\mathrm{Asn}^{78}$, a residue that is probably close to the junction between helix $\mathrm{B}$ and the loop connecting helix B to C. Variability in glycosylation is not uncommon within IFN subtypes (56), but its significance is unclear. An aglycosyl recombinant form of boIFN $\tau$ has been prepared in Escherichia coli, is relatively stable, and possesses biological properties typical of other type I IFN (76).

\section{Bioactivities of the Trophoblast IFN}

\section{A. Antiviral, antiproliferative, and immunomodulatory properties}

The structural similarity of the IFN $\tau$ to other type I IFN has been born out in their biological properties. They can, for example, protect several cell types known to possess type I receptors from lysis by a range of viruses, including the commonly employed vesicular stomatis virus, with at least an equivalent potency to IFN $\alpha$ 

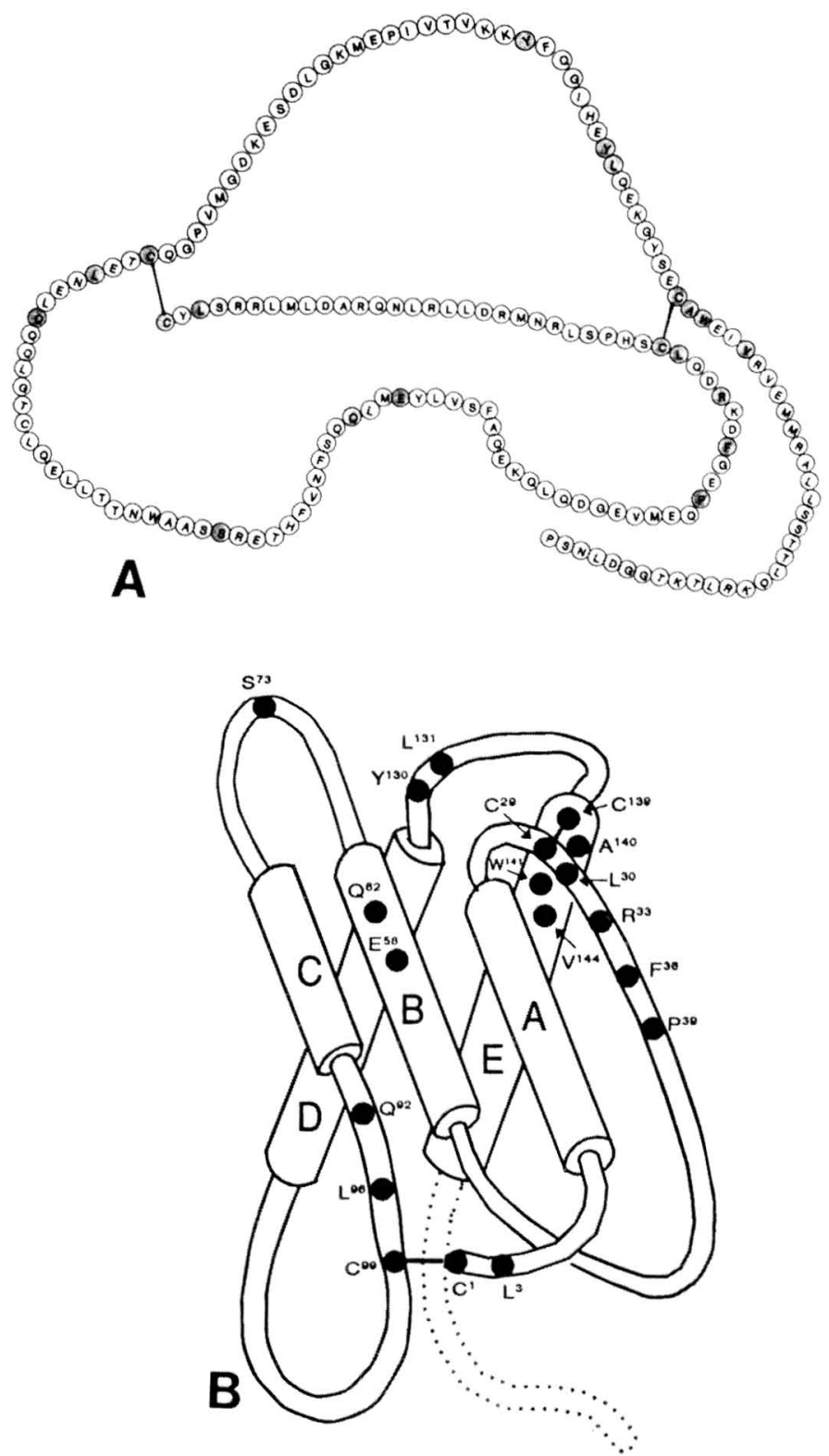

FIG. 1. A, A diagram showing the primary structure of an ovIFN $\tau$ deduced from the cDNA sequence oTP-1p6 of Klemann et al. (51). The shaded circles indicate amino acids that are conserved in most known type I IFN. Disulfide bonds are indicated by lines. The $\mathrm{NH}_{2}$-terminal residue is Cys while the $\mathrm{COOH}$-terminal residue is Pro.

$\mathrm{B}, \mathrm{A}$ diagram showing a predicted three-dimensional structure of a type I IFN. This model is based roughly upon the theoretical conformation analysis of Zav'yalov et al. $(71,72)$ and a brief written description of the crystal structure of mouse IFN $\beta$ provided by Senda in an abstract (75). The former predicted a three-dimensional structure of five antiparallel helices similar to that of IL-2. Senda et al. (75), however, showed that in IFN $\beta$, unlike IL-2, the helices A and B were parallel to each other and that helix $A$ was considerably longer than had been predicted. The five $\alpha$-helices are A (residues 6-23), B (50$65), \mathrm{C}(79-88), \mathrm{D}$ (112-129), and E (137-152). The 20-residue carboxyl tail, whose conformation on IFN $\omega$ and IFN $\tau$ is unknown, is shown with a broken line extending below the molecule, but could well fold back across the helical core. The $\mathrm{Cys}^{1}-\mathrm{Cys}^{99}$ disulfide bridge is not present on all IFN $\beta$ but is present on other type I IFN. Seventeen of
(76-82). The IFN $\tau$ can also markedly slow the proliferation of bovine kidney epithelial cells $(78,83)$ and human WISH cells (83) over roughly the same concentrations at which most IFN $\alpha$ are growth inhibitory. However, at high concentrations, ovIFN $\tau$ has been noted to be far less cytotoxic than either boIFN $\alpha$ or a huIFN $\alpha$ preparation (83). Consequently, IFN $\tau$ have been claimed to constitute a "cell friendly" class of IFN $(83,84)$. Such claims for unique properties of IFN $\tau$, however, must be balanced against observations of striking differences in pyrogenicity, cytotoxicity, and antiproliferative properties between individual human IFN $\alpha$ subtypes, particularly when cross-species comparisons have been made (reviewed in Ref. 85).

The IFN $\tau$ strongly inhibit incorporation of $\left[{ }^{3} \mathrm{H}\right]$ thymidine into lymphocytes after exposure to mitogens (78, 86-89) or after placement in culture with "foreign" lymphocyte populations (89). Again, however, $\operatorname{IFN} \tau$ and IFN $\alpha$ provide comparable effects over a similar range of concentrations, and there has certainly been no evidence that either ovIFN $\tau$ or boIFN $\tau$ exhibit any unusual biological properties that set them aside from other type I IFN.

The IFN $\tau$ are capable of up-regulating at least one of the enzymes that has been implicated in the metabolic responses of cells to type I IFN. Endometrial synthesis of 2,5-oligoadenylate synthetase, for example, is markedly enhanced by IFN $\tau$ (90-92). However, an almost equivalent response occurs with hu- and boIFN- $\alpha$.

Both boIFN $\alpha$ and IFN $\tau$, with about equal potency, markedly up-regulate a highly acidic $70,000 \mathrm{Mr}$ secretory protein in both ovine endometrial explants $(29,93,94)$ and cultured uterine epithelial cells (95). This same protein has been observed to be a product of endometrium in contact with trophoblast only during the period of ovIFN $\tau$ production (96) and to be induced when nonpregnant ewes are injected with boIFN $\alpha$ (94). It remains to be identified functionally.

All the above data show that the IFN $\tau$ are bona fide type I IFN with little to distinguish their biological properties from those of IFN $\alpha$.

\section{B. Comparative effects of IFN $\tau$ and $I F N \alpha$ on reproductive parameters}

The most striking biological effect of the IFN $\tau$, oTP1 , and bTP-1 has been their ability to prolong the estrous cycle and lifespan of the CL when infused into the uteri of nonpregnant sheep or cattle $(35,36,79,97-99)$. Purified "natural" ovIFN $\tau$, which consists of at least three to

the 18 highly conserved residues, with $\mathrm{Y}^{123}$ hidden on helix $\mathrm{D}$ behind helix B, as well as $\mathrm{Cys}^{1}$ and $\mathrm{Cys}^{99}$, are shown as closed circles. Note the highly conserved region where the A-B loop (24-49) and helix E are in close juxtaposition. 
four distinct isoforms, and recombinant products, which are, of course, products of single genes, appear equally effective in this regard $(79,97)$. The daily intrauterine infusion of either type of preparation into nonpregnant ewes was able to extend estrous cycle length from days to weeks relative to control ewes. The concentrations chosen in the sheep experiments (100-250 $\mu \mathrm{g} /$ day) had been calculated to approximate the daily amount of the mixture of isoforms of ovIFN $\tau$ secreted by conceptuses at the peak time of production (around day 15). By contrast, however, boIFN $\alpha$ was ineffective in ewes when used at such low concentrations (100) and was able to induce only a minimal response (2 to 3 days extension) in both cattle $(101,102)$ and sheep (100) when doses exceeding $1 \mathrm{mg} /$ day were employed. Relatively large intramuscular injections also delayed luteolysis for a few days in both species $(102,103)$ but never for an extended period. Strikingly, however, such an injection regimen of boIFN- $\alpha$ maintained over the day 11-18 period, when IFN $\tau$ would normally be produced, has been used successfully to improve fertility in ewes in a series of breeding trials (104-106). The rationale for these experiments was that the injected IFN would supplement the activity of endogenously produced oTP-1 and ensure a complete maternal response in the mother in cases where the conceptus might be small or otherwise lagging in its development.

Although intramuscular injections of boIFN $\alpha$ also produced a slight increase in estrous cycle length in cattle $(102,103)$, a comparable beneficial outcome on fertility has not been observed, and serious side effects were noted in animals following the initial injections $(103,107,108)$. The symptoms, fever and malaise, were not unlike those noted after IFN $\alpha$ therapy in humans (85), and the elevation in body temperature may have contributed to embryonic loss. It will be of interest if $\operatorname{IFN} \tau$, which can now be readily prepared by a variety of recombinant procedures $(76,79-81,109)$ and in practicable amounts for animal experimentation, have similar adverse side effects when injected intramuscularly into cattle. Conceivably if they are less pyrogenic than boIFN $\alpha 1$, they might become useful fertility agents. As mentioned earlier, different species are known to vary markedly in their responses to foreign IFN, and individual IFN subtypes can elicit widely different pyrogenic effects even in the same species (85).

What underlies the ability of the IFN $\tau$ to prolong luteal lifespan and why are the IFN $\tau$ so much more efficient than IFN $\alpha$ in this regard? As outlined earlier, all evidence is consistent with the view that luteolysis in large ruminant species is prevented by intervention in the pulsatile production or release of PGF by the endometrium (reviewed in Refs. 26 and 27). Intrauterine administration of either whole conceptus secretory pro- teins or purified IFN $\tau$ reduces the number and amplitude of luteolytic pulses of PGF $(25,37,110)$. Nevertheless, despite somewhat conflicting evidence that type I IFN, including IFN $\tau$, can inhibit PGF synthesis $(91,111-114)$, the endometrium of pregnant ewes (but not of cattle) appears to produce as much or possibly even more basal amounts of PGF than cyclic ewes $(26,27)$. Therefore, the antiluteolytic effects of IFN $\tau$ in ewes may have more to do with the release rather than inhibition of biosynthesis of prostaglandin. In this regard, attention has now shifted to the control of PGF pulsatility and to the role of oxytocin in this process. This small peptide, by binding to its surface receptor, is believed to induce PGF release by the endometrium and is probably responsible for the pulsatile nature of the response $(26,27,115,116)$. In ewes, oxytocin receptors increase in the critical day 12 14 period preceding the onset of luteolysis but are downregulated during pregnancy and after IF $\mathrm{N} \tau$ administration $(26,88,115-117)$. As a consequence of these data, it has been suggested that the buildup of oxytocin receptors that occurs in the estrous cycle is reversed by IFN $\tau$ treatment (84).

\section{Interaction of IFN $\tau$ with type I receptors}

High affinity, low capacity binding of ovIFN $\tau$ to receptors in endometrium was first reported by Godkin et al. (29). These receptors were assumed to mediate the complex physiological responses, including the marked changes in protein synthesis that occurred when the endometrium was first exposed to ovIFN $\tau$ during early pregnancy (29). Stewart et al. (47) later showed that purified ovIFN $\tau$ displaced $\left[{ }^{125}\right.$ I] huIFN $\alpha$ from such receptors and thereby confirmed that the former was a type I IFN. Equilibrium-binding studies have revealed dissociation constant $\left(\mathrm{K}_{\mathrm{d}}\right)$ values in the range of $0.1 \times 10^{-10} \mathrm{M}$ to $0.4 \times 10^{-10} \mathrm{M}(47,118,119)$, values that seemed to vary slightly according to the stage of the estrous cycle (119). In addition, some evidence has been provided for a group of lower affinity sites $\left(\mathrm{K}_{\mathrm{d}} \sim 10^{-10} \mathrm{M}\right)$ (118) and may correspond to the ones first noted by Godkin et al. (29). However, since secreted ovIFN $\tau$ is a mixture of at least four isoforms, it is possible that the noted complexity of binding was the result of varying affinities of different subtypes for a single receptor, a phenomenon well known among the IFN $\alpha(56,120,121)$. The binding constants observed were well within the broad general range of those expected for specific binding type I IFN to receptor (120).

One anomalous observation regarding IFN $\tau$ binding to its receptor needs to be explained. Hansen et al. (118) used the bifunctional cross-linking reagent disuccinimidyl suberate to show that $\left[{ }^{125} \mathrm{I}\right]$ ovIFN $\tau$ became associated with at least two polypeptides $(\mathrm{Mr} \sim 100,000$ and $\sim$ 
70,000 ) and could be displaced from both by boIFN $\alpha$. By contrast, boIFN $\alpha$ could only be cross-linked to the larger binding protein. Since proteolysis did not appear to be responsible for creating the two polypeptides, these experiments can be interpreted in at least two ways. Either there is a unique $\operatorname{IFN} \tau$ receptor polypeptide (in which case the displacement by boIFN $\alpha$ is hard to explain),or else the oTP-1 employed possessed reactive lysine residues that were more in a position to react and form crosslinks to the $70,000 \mathrm{Mr}$ protein than equivalent residues in boIFN $\alpha$. The latter explanation implies that the IFN receptor may always consist of more than one polypeptide. Thus, one of the two "subunits" (most likely the $100 \mathrm{~K}$ form) probably corresponded to the 557 amino acid transmembrane glycoprotein cloned by Uze et al. (122). Transfection experiments have shown that additional components are most likely required for this receptor polypeptide to assume high affinity binding and to mediate biological responses $(122,123)$. The second subunit (the $70 \mathrm{~K}$ form) may be such an accessory protein that becomes fortuitously cross-linked to one or more of the isoforms of ovIFN $\tau$, but not to boIFN $\alpha$. The two binding proteins do not constitute a unique endometrial receptor, since a similar pair of polypeptides was noted when ovIFN $\tau$ (but again not when boIFN $\alpha$ ) became cross-linked to spleen receptors (118). Multiple subunit receptor complexes have recently been described for a broad range of cytokines $(124,125)$.

The likely manner in which type I IFN, including IFN $\tau$, interact with receptor polypeptides is still unclear. Large numbers of experiments have been carried out over the past decade to map regions of the IFN $\alpha$ molecule that are crucial for either receptor binding, biological activity, or both. Approaches have included a comparison of naturally occurring allelic subvariants that exhibit very different activities $(126,127)$, alterations in specific residues, or whole domains on the IFN by site-directed mutagenesis $(128,129)$, inhibition of binding or activity with antibodies directed to specific epitopes $(130,131)$, and competition binding studies with specific peptides (132). These results are best interpreted by examining the model shown in Fig. $1 \mathrm{~B}$ and can be briefly summarized as follows. The disulfide bond $39-139$ is always required for activity, while the 1-99 bond is necessary in only some IFN $\alpha$ (in others the entire $\mathrm{NH}_{2}$-terminus can be eliminated). At least part of helix $\mathrm{A}$ and the well conserved loop between helices A and B participate in receptor binding and contribute to antiviral potency and antiproliferative activity. A carboxyl-terminal domain stretching from at least the middle of helix $\mathrm{D}$ to the end of helix $\mathrm{E}$ interacts with the receptor and is also necessary for biological activity. The carboxyl tail, from residue 152 to 162 in IFN $\alpha$, appears to be largely disposable. It should be emphasized that not all substitutions within the crucial regions may necessarily have an effect. Similarly, some changes outside those discussed can measurably change receptor binding affinity, possibly by subtly altering packing or folding of the structure.

Very few complementary studies have been performed to confirm these general rules with the IFN $\tau$. Pontzer et al. (133) showed that relatively high concentrations of an $\mathrm{NH}_{2}$-terminal peptide (residues 1-37) negated antiviral activity of ovIFN $\tau$ but not that of "natural" IFN $\alpha$. Antibodies to this domain also inhibited ovIFN $\tau$ receptor binding. By contrast, a carboxyl- terminal peptide (residues 139-172) effectively inhibited the antiviral activity of both kinds of IFN subtypes. It was concluded that the $\mathrm{NH}_{2}$-terminal domain of ovIFN $\tau$ binds to a unique site on the receptor complex. However, these observations are clearly open to more than one interpretation and do not in themselves contradict the general rules of IFNreceptor interaction discussed above.

The data are consistent with the view that IFN $\tau$ binds to the same receptor or receptor complex as other type I IFN with roughly similar affinity. It remains to be confirmed whether some of the unusual properties of IFN $\tau$, such as their ability to extend the length of the estrous cycle, depend upon interaction with a secondary accessory protein on the receptor complex.

\section{Second messenger systems for the IFN $\tau$}

Type I IFN appear to initiate their effects through activation of latent transcription factors that then bind to IFN response elements on selected target genes (134, 135). Considerable controversy exists, however, about the signal transducing pathway utilized after the IFN first binds to its receptor. The one receptor polypeptide so far identified (122) carries no obvious intracellular protein kinase or phosphatase domains and bears no resemblance to the seven-helix receptors known to interact with $G$ proteins. The signaling components may well reside on one or more of the so far uncharacterized accessory proteins and activate a completely novel signal transduction system. Evidence has been presented for IFN activation of a protein kinase $\mathrm{C}$ and for diacylglycerol production in human lymphoblastoid cells (136), while a transient stimulation of phospholipase $\mathrm{A}_{2}$ with a rapid accompanying release of arachidonic acid has been reported in mouse fibroblasts (137). The latter pathway might be expected to increase rather than decrease prostaglandin synthesis in endometrial tissue.

Information on second messenger system activity in the uterus is limited. cAMP concentrations fell and cGMP increased slightly in endometrial explants from nonpregnant ewes exposed to ovIFN $\tau$, while $(\mathrm{Bu})_{2} \mathrm{cAMP}$ antagonized the specific effects of the interferon on endometrial protein synthesis (94). The phosphatidyli- 
nositol cycle has been reported to be stimulated in some experiments (138), but in others (139) ovIFN $\tau$ appeared to inhibit the rise in inositol triphosphate and total inositol phosphates that occurred when endometrial tissue from day 16 of the cycle was exposed to oxytocin, a hormone that stimulates prostaglandin release $(26,27)$. In summary, the signal transduction systems employed by type I IFN in general and by IFN $\tau$ in particular are unclear. This situation may remain confusing until more is known about the receptor system as a whole.

\section{The Expression of IFN During Pregnancy}

\section{A. Are Type I IFN expressed universally by embryonic and placental tissues?}

The first report of IFN expression by uninduced tissues from the feto-placental unit was in mice (140). Since that time these observations have been extended to several other mammalian species including the ruminants, hamster, pig, and human and have been summarized in other reviews $(3,10)$. The finding that a potent cytokine is expressed at the placental-maternal interface has prompted the suggestion that IFN must play a universally important role in the establishment and/or maintenance of pregnancy (59). A likely function of these IFN has been proposed to be the modulation of the maternal immune system $(141,142)$, but data in support of this hypothesis are lacking, and no specific target cell type has been defined. Certainly, however, in species outside the Bovidae there is no evidence that type I IFN have an antiluteolytic role. In pig, for instance, infusion of whole conceptus secretory proteins failed to extend estrous cycle length in nonpregnant gilts (143). Indeed, estrogen appears to be the primary antiluteolysin in swine (25).

It should also be stressed that, while IFN may be expressed by conceptuses and placental tissues of many species, the nature and amount of the IFN released differ markedly. From a comparative standpoint, those IFN that are produced when placentation first begins have been of particular interest, because it is at this stage when the attention of the maternal immune system may be first drawn to the presence of the conceptus. Antiviral activity, suggestive of IFN, is produced by peri-implantation conceptuses of several nonruminant species including mice (144), pigs $(60,61,145,146)$, horses (147), and rabbits (148). Whereas ovine and bovine conceptuses produce several million units of antiviral activity in culture $(10,149,150)$, maximal production of antiviral activity reported for these other species is 1,000- to 10,000 -fold less. Such low amounts probably explain why some groups have failed to detect any production of antiviral activity by preimplantation equine (151), human (151), and mouse conceptuses $(152,153)$. With day 4 mouse blastocysts, for example, antiviral activity was only detected by direct coculture of conceptuses with target cells (144).

Our understanding of the antiviral activities that are produced around implantation in nonruminant species has been hampered because the factors have often been incompletely characterized both serologically and biochemically. Antisera against various IFN subtypes have been used for identification purposes, but it is clear that such data can be misleading, since these assays cannot always distinguish between legitimate IFN and other substances that may simply induce the target cells in the antiviral assay to produce IFN themselves (154). The use of DNA probes to detect and clone IFN mRNA from conceptus tissues should soon begin to advance the field greatly. At present this approach has not been successful in species other than the pig, in which the primary IFN produced by peri-implantation conceptuses is $\operatorname{IFN} \gamma(60$, 61). Coexpression of a type I IFN also occurs, however, since an antiserum against human IFN $\alpha$ detected a $22,000 \mathrm{Mr}$ protein on Western blots of conceptus culture medium (145), and a different antiserum against human "leukocyte IFN" partially neutralized the antiviral activity produced by conceptuses $(61,146)$. On the other hand, a porcine IFN $\alpha$ DNA probe did not detect transcripts in Northern blot analysis or cDNA library screening (Cross, J. C., and R. M. Roberts, unpublished results). Screening of a porcine genomic library with a porcine IFN $\omega$ probe has identified an unusual kind of type I IFN gene that is related to IFN $\omega$ but clearly distinct from IFN $\alpha$ and IFN $\tau$ (155). It is still unclear, however, whether this IFN $\omega$ represents the type I IFN secreted by the porcine conceptus. Together these data imply that the pig may be quite different than the ruminants in the kind of IFN expressed and in the roles these IFN play, despite the tempting desire to consider all species similar and to present a unifying hypothesis (59).

Immunoneutralization antiviral assays of mouse (144) and horse (147) conceptus culture media all implicated a type I IFN as being responsible for the antiviral activity. Extensive Northern blotting and in situ hybridization analyses have been conducted with murine IFN $\alpha$ and $\beta$, and equine IFN $\alpha$ and $-\omega$ probes in their respective species, as well as IFN $\tau$ probes across species, in an effort to identify transcripts related to type I IFN. To date all have failed (Ref. 144 and Farin, C. E., and R. M. Roberts, unpublished data). These experiments indicate either that the IFN produced were not the type I IFN subtypes that were addressed, or that the mRNA were present at extremely low levels.

The conclusion from studies in several mammalian species is that IFN genes are expressed during the periimplantation period of normal pregnancies. The implication, therefore, is that cells within the conceptus at this period differentiate and produce IFN, often in very 
small amounts, either as a consequence of an autonomous developmental cue or in response to a maternal stimulus that is universally present during mammalian embryogenesis. Thus, the phenomenon might be expected in some of its aspects to mimic the normal induction pathway for the IFN genes by virus, and other virusresponsive IFN genes might, therefore, be anticipated to be minimally expressed during the peri-implantation period.

\section{B. Maturation of the IFN system during embryonic development}

It has been recognized for several years that the ability of cells to respond to both IFN and IFN inducers is dependent on the state of differentiation of those cells. For example, chicken embryo cells from later developmental stages produce more IFN in response to an inducer than cells from earlier stages (156). Similarly, chicken embryo cells produce more IFN after being "aged" in vitro (157). Several mammalian embryonal carcinoma (EC) cells have been established that share features with pluripotent embryonic stem cells (158). Undifferentiated EC cells are completely nonresponsive to IFN and to IFN inducers, whereas EC cells induced to differentiate, e.g. with retinoic acid, gain the ability to respond to IFN and to produce IFN (159-162). The lack of responsiveness to IFN may not be due to a lack of IFN receptors on these cells (163) but rather may relate to a defect in the activation of the IFN-induced antiviral mechanisms, such as the absence of double-stranded RNA-dependent protein kinase.

The maturity of the IFN system is also linked to the developmental age of the conceptus. For example, murine conceptus tissues could be virally induced to produce antiviral activity, but expression was restricted to tissue derived from outside the inner cell mass, e.g. trophoblast, and the induced antiviral activity was not apparent until after day 7 of gestation, approximately 2 days after implantation (152). Preimplantation murine conceptuses were not protected by IFN from viral challenge (164). Few studies have been done with conceptuses from other mammalian species, although day 10 bovine conceptuses were not protected by IFN from viral infection in vitro with vesicular stomatitis virus (165). Treatment of similar stage conceptuses with the IFN inducer poly(I):poly(C) did elicit the antiviral response, however, although the nature of the IFN, e.g. whether it was IFN $\tau$, was not determined (166). The apparent contradiction between these two studies suggests that maturation of the IFN system, i.e. the ability to produce and to respond to IFN, may occur around day 10 in the bovine conceptus.

The discovery that IFN inducibility is restricted to trophoblastic cells in the murine conceptus is intriguing in view of the highly localized expression of IFN $\tau$ to the ovine and bovine trophectoderm (Section IV.D) and suggests a basic difference between these cells and those of the inner cell mass. Few studies have examined IFN inducibility in trophoblast. Primary cultures of partially purified cytotrophoblast from human term placentas can produce a small amount of IFN $\beta$ in response to poly(I):poly(C) (167). Syncytiotrophoblast produced less antiviral activity than the nonfused cytotrophoblast cells, and the transformed trophoblast cell line, JAR, was even less responsive.

Experiments using mammalian conceptuses and EC cells all suggest, therefore, that the maturation of the IFN system is dependent on a certain degree of cellular differentiation, and that IFN-competent cells possess a repertoire of inducible transcription factors distinct from that in undifferentiated cells. Present information on how IFN-inducible genes and the IFN genes themselves are regulated now suggest that the two pathways are interconnected, perhaps by a common set of transcription factors that includes interferon regulatory factor- 1 (IRF-1) (134). It would be anticipated, therefore, that both the onset in the responsiveness to IFN and the inducibility of IFN genes themselves would occur coincidentally during development. The details on how the IFN system matures during embryonic development are only now beginning to emerge.

The process of EC cell differentiation is associated with the loss of a nuclear protein able to bind the IFN $\beta$ promoter (168). This result suggests a model in which a dominant repressor protein complex inhibits activation of the IFN $\beta$ promoter in the undifferentiated state. Consistent with such a "dominant repressor model" is the observation that the differentiation process is associated with the development of DNase I sensitivity in the IFN $\beta$ promoter (169). The DNA element that serves as the putative repressor binding site is a degenerate form of the "octamer" sequence (170) and is present close to the upstream boundary of the virus response element of the IFN $\beta$ promoter (Section IV.C). The identity of the inhibitory factor is unclear, although octamer-binding proteins that are expressed in undifferentiated, but not differentiated, EC cells have been described (171).

Recently it has also become apparent that at least one of the transcriptional control systems involved in type I IFN expression matures coincidentally with EC cell differentiation (172). In undifferentiated EC cells both IRF1 (transactivator) and IRF-2 (repressor) are absent, and type I IFN genes are not virally inducible. Overexpression of IRF-1 alone, however, induces IFN gene expression and affords virus inducibility. After differentiation, both IRF-1 and IRF-2 are expressed in EC cells, and the IFN system becomes both inducible and subject to downregulation. 
What do these observations tell us about the control of IFN $\tau$ expression during embryogenesis? They may explain why the genes are not transcribed in the inner cell mass, presumably as a result of silencing by one or more major repressors that may affect all type I IFN genes. Second, there may be an absence of potential transcriptional activators such as IRF-1. The studies also suggest that at about the time the IFN $\tau$ are first expressed constitutively, when trophoblast differentiation is being initiated, the IFN system as a whole matures and other type I IFN become potentially inducible by virus.

\section{General features of transcriptional regulation of $I F N \alpha,-\beta$ and $-\omega$}

Although there are reports of low constitutive expression in a variety of tissues (173-175), type I IFN genes generally appear to be silent until induced by virus and thus play a major role in host defense against viral infection. A range of other factors, including several cytokines, can also act as inducers in certain cell types $(56,176)$.

Even though primary regulation of $\operatorname{IFN} \alpha$ and $-\beta$ is transcriptional, expression is invariably transient, rarely lasting more than a few hours even in continuous presence of inducing agent (56). Thus, the initial high rate of mRNA production is quickly repressed, and IFN synthesis slows. The short half-lives of the transcripts (177, 178), which have adenosine/uridine rich destabilizing motifs in their $3^{\prime}$-untranslated termini (see Refs. 46, 176, 179 , and 180), presumably contribute to this sharp drop in IFN expression. These general rules do not appear to apply to IFN $\tau$, which are only weakly inducible by virus and whose synthesis appears to be sustained over a period of days rather than hours.

Transcription of the IFN $\beta$ gene has been intensively studied (see Ref. 181) because in most species it is represented by a single copy that is inducible in cultured fibroblasts. Transcriptional control is complex, even though only the promoter region up to about position 120 above the transcriptional start site is required for high levels of virus induction. Within this region there are at least four overlapping but distinct positive regulatory domains (PRD I though IV) that have been implicated in virus inducibility. Flanking the entire virus response element are two negative response domains that maintain the gene in a silent state under noninducing conditions. Each of the PRD is capable of conferring viral inducibility when multimerized upstream of reporter genes but also appear capable of responding to various nonviral inducers $(181,182)$. For example, PRD I is IFN-inducible while PRD II and IV are responsive to phorbol esters and cAMP, respectively. Not surpris- ingly, several transcription factors have been identified which interact with the IFN $\beta$ promoter, most notably NF- $\kappa \mathrm{B}$ (183), which binds PRD II, and interferon regulatory factor-1 (IRF-1) $(184,185)$, which interacts with at least three purine-rich regions containing the motif $\mathrm{AA}(\mathrm{G} / \mathrm{T})(\mathrm{T} / \mathrm{G}) \mathrm{GA}$ overlapping all four PRD (Fig. 2). IRF-2, a repressor, can bind to these same sequences and may, in part, be responsible for the subsequent postinduction silencing of the IFN $\beta$ gene $(186,187)$. Although IRF-1 has been implicated as a major participant in expression of both IFN $\beta$ and IFN-inducible genes (134, $135,172,181,188)$, efficient induction clearly depends upon interactions among many mini-enhancer sites so as to provide a flexible and graded response to virus and various modulating stimuli.

The IFN $\alpha$ are often coexpressed with IFN $\beta$ and are also efficiently virus-inducible (56). The study of IFN $\alpha$ promoters, however, is less advanced, in part because the human and murine genomes possess at least 15 potentially functional IFN $\alpha$ genes which differ only subtly in sequence yet which appear to vary widely in virus inducibility (189). Nonetheless, as with the IFN $\beta$, only about $120 \mathrm{bp}$ of the $5^{\prime}$ promoter region are required for full virus responsiveness (190). NF- $\kappa \mathrm{B}$ binding sites are not present in any known IFN $\alpha$ promoter, although several potential binding sites for IRF-1 do exist, and IFN $\alpha$ promoters effectively compete for IRF-1 binding (184). A GAAATG motif, not found in the IFN $\beta$ promoter, is present in the human IFN $\alpha 1$ promoter (191) (Fig. 2). It binds a factor distinct from IRF-1, the TG-protein which has not been fully characterized, and it is unclear whether it represents a transactivator, although multimerization of the TG-protein binding motif creates a virus-inducible enhancer.

Descriptions of the regulation of other type I IFN have not been made. Genes for human (63), porcine (155), ovine $(52,192,193)$, and bovine $(53,63)$ IFN $\omega$ have been cloned. They possess considerable sequence identity with

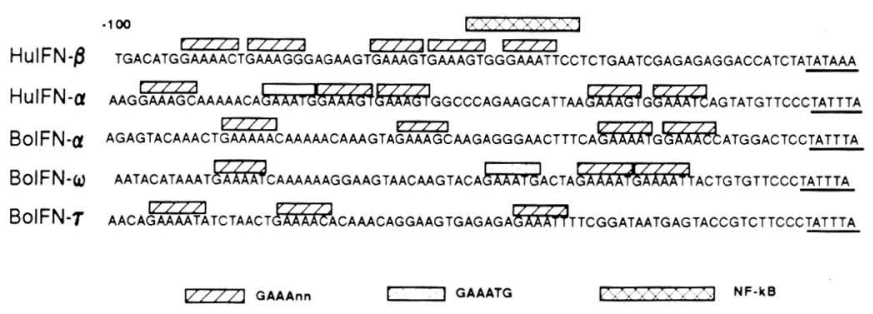

FIG. 2. A comparison of the promoter regions for type I IFN genes. The sequences upstream of the TATA box for human IFN $\beta$ and IFN $\alpha 1$, for the boIFN $\alpha 1$ and IFN $\omega 1$ and for the boIFN $\tau$ genes are aligned. The position of the hexamers with the sequences AAATGA (which is thought to bind the transcription factors IRF-1 and IRF-2), GAAANN, GAAATG, and a motif that binds the NF- $\kappa$ B transcription factor are indicated by shaded rectangles. [The data are from $\mathrm{Du}$ et al. (182), Hansen et al. (53), Harada et al. (1987), Lenardo et al. (191), and MacDonald et al. (191).] 
the IFN $\alpha$ genes upstream of the transcription start site (Fig. 2), and so it has been assumed that IFN $\alpha$ and $-\omega$ genes share common transcriptional regulatory mechanisms. In the human, where there is probably only one functional gene (194), IFN $\omega$ is clearly virus inducible (63, 64 ) and constitutes $15 \%$ of the antiviral activity released by virus-induced leukocytes $(68,195)$.

\section{IFN $\tau$ genes are regulated in a cell-and developmentally specific manner}

1. Trophoblast cell expression. Whereas other type I IFN genes are expressed in a variety of cell types after appropriate induction, several lines of evidence support the view that the trophoblast IFN are unique by virtue of the restricted pattern in which they are expressed. This apparent "cell specificity" was suspected when primary structure analysis revealed that the trophoblast IFN constituted a separate subtype that had not been observed in the cloning of cDNA from virally induced cells.

Before identification of oTP-1 and bTP-1 as IFN, it was known that the intrauterine transfer of isolated trophoblastic vesicles extended luteal function in cyclic sheep and cattle (196). It seemed likely, therefore, that the antiluteolytic factor was a product of the embryonic trophectoderm. This hypothesis was confirmed by the immunocytochemical localization of $\operatorname{IFN} \tau$ to the trophectoderm, a cell layer derived from the first epithelium of the blastocyst, which forms the outer epithelial layer of the trophoblast (29, 197-199). In situ hybridization techniques have also permitted specific detection of IFN $\tau$ transcripts in trophectoderm (197, 200-202). This mRNA was highly localized, with transcripts entirely absent from the underlying extraembryonic endoderm, the yolk sac, the amnion, and the entire embryonic disc. Furthermore, within the trophectoderm itself, only mononucleate cells appeared to produce $\operatorname{IFN} \tau(197,198)$. Binucleate cells, which are scattered among mononucleate cells by day 16 in sheep $(15,16)$, exhibited little or no immunocytochemical staining.

The interesting observation has also been made that at the attachment sites of the trophoblast to the uterine wall, a process that begins around day 16 in sheep, ovIFN $\tau$ expression in cells adhering to uterine epithelium was reduced $(197,199)$. By day 22 , when most of the trophoblast was attached, expression of ovIFN $\tau$ was virtually undetectable. Thus, contact between the trophoblast and the uterine epithelium appeared to inhibit ovIFN $\tau$ gene expression.

It is curious that the protooncogene, c-fos, exhibits an almost identical pattern of expression to IFN $\tau$ in ovine trophoblast tissue, increasing up to the time of attachment and declining in cells having contact with the uterine epithelium (199). Conceivably c-fos is induced by
IFN $\tau$ or is itself a component of a transcriptional complex that activates IFN $\tau$ genes, even though no interferon response elements are associated with the c-fos gene, and no well conserved AP-1 binding sites have been found in the upstream promoter regions of $\mathrm{IFN} \tau$ genes identified to date (see Section IV.E). Alternatively, both c-fos and IFN $\tau$ genes may be regulated by common mechanisms during this period of rapid cellular proliferation and differentiation of trophectoderm.

These observations of cell-specific expression imply that only cells of trophoblast origin transcribe the IFN $\tau$ genes, presumably because they possess unique transacting factors important for proper gene expression. A boIFN $\tau$ gene was transfected into human choriocarcinoma (JAR) cells to test this hypothesis (150). Such cells do not normally secrete detectable amounts of antiviral activity and do not possess a gene homologous to the ruminant IFN $\tau$ (Section V.A). Nonetheless, JAR cells transfected with the bovine gene secreted antiviral activity, whereas several nontrophoblast cell lines tested did not, supporting the notion that expression of the IFN $\tau$ genes is the result of factors unique to cells of trophoblast origin. In contrast, a similarly transfected bovine IFN $\omega$ gene was not expressed, demonstrating a functional difference between these two subtypes of IFN. Even so, the expression achieved in JAR cells was only a fraction of that which occurs in bovine or ovine trophoblast, making it likely that a complete, balanced complement of required transcription factors is not present in the human cells.

2. Temporal pattern of expression. Although ovIFN $\tau$ production can be detected in cultured blastocysts as early as day $8-10$ of pregnancy by using a highly sensitive immunoassay (149), large-scale production is restricted to days 13 to 21 when the conceptus is undergoing rapid expansion from a spherical to an elongated form $(10,28$, 149, 203) (Fig. 3). Two-dimensional fluorographs of radiolabeled ovine conceptus secretory proteins clearly demonstrate the three to four main isoforms of ovIFN $\tau$ to be the dominant secretory products during this elongation period (28). Transcripts for ovIFN $\tau$ are detectable by in situ hybridization in day 10 and 11 spherical blastocysts (200-202), but increase markedly (5- to 10fold) in concentration per cell by day 13 (200). The concentration of mRNA then declines slightly by day 15 and precipitously thereafter as judged by Northern blotting $(49,50,204)$ or in situ hybridization (197, 200). Therefore, the increase in ovIFN $\tau$ synthesis observed between days 13 and 15 by whole conceptuses probably reflects the 20 -fold increase in tissue mass that is observed during that period of extraordinary growth (205) rather than an increase in mRNA per cell. Overall, there appears to be a good correlation between the total 

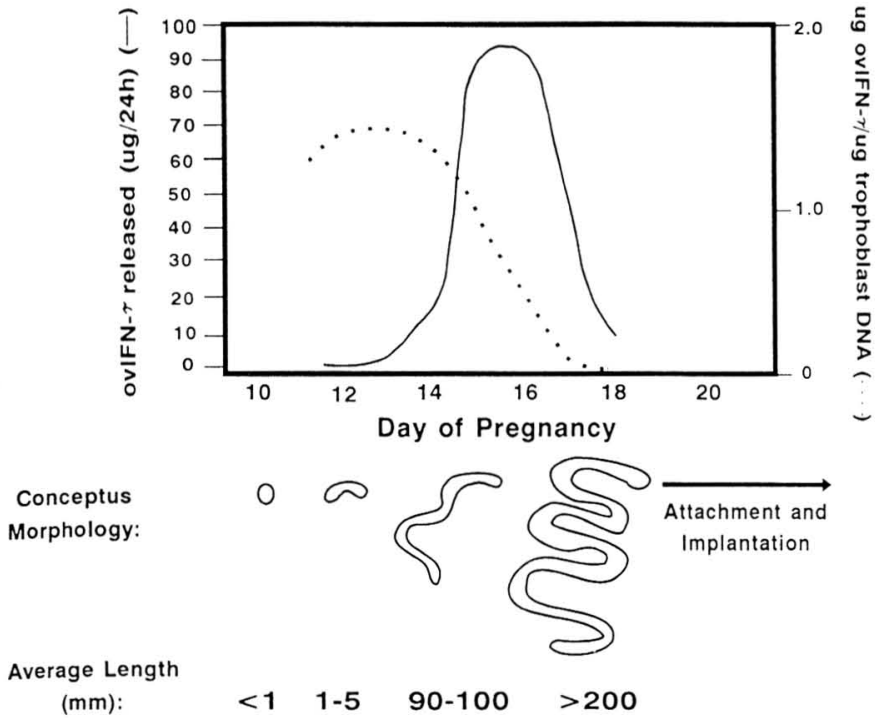

FIG. 3. A diagram showing the relationship between day of ovine conceptus development and 1) amount of ovIFN $\tau$ produced when individual conceptuses were placed in culture (S) and 2) the amount of ovIFN $\tau$ produced per $\mu \mathrm{g}$ of trophoblast DNA (broken line). The values for IFN produced are derived from Table 2 of Ref. 10. Antiviral units were converted to amount of IFN $\tau$ on the basis of the rough equivalency of $10^{7}$ laboratory units and $1 \mathrm{mg}$ ovIFN $\tau$. Values for ovIFN production are consistent with those published by Ashworth and Bazer (149) who used an immunoassay to measure ovIFN $\tau$. The amount of DNA was estimated from the data of Wales and Cunea (205) who made measurements of dry weight, and protein and DNA content per trophoblast on days $13,15,17$, and 19. Average conceptus lengths were derived from Refs. 205 and 224.

ovIFN $\tau$ mRNA content of the tissue and the amount of protein produced.

BoIFN $\tau$ displays a similar pattern of expression as $\operatorname{ovIFN} \tau$, with synthesis peaking between days 17 and 19, thereby reflecting the comparatively later timeframe of maternal recognition of pregnancy in cattle (201). Although both synthesis of boIFN $\tau$ (31) and the concentration of its mRNA (201) decline after day 19, the protein continues to be produced at low levels until at least day 35 (206). The transient production of the IFN $\tau$ suggests that the initiation of expression is triggered either by an autonomous developmental change within the trophoblast cells themselves or by an external stimulus provided at the appropriate time within the uterine environment.

The initial secretion of boIFN $\tau$ antiviral activity (207) and the appearance of boIFN $\tau$ transcripts $(207,208)$ can first be detected at about the time the bovine blastocyst begins to expand and hatch from the zona pellucida, i.e. equivalent to day 8-9 in vivo. However, because these experiments were performed on conceptuses derived entirely under in vitro conditions, i.e. from oocytes matured and fertilized in vitro and cultured to the expanded blastocyst stage in the laboratory, it seems likely that this initial expression of $\operatorname{boIFN} \tau$, when a functional trophectoderm is first formed, is a genetically programmed event. Interestingly, although such in vitroproduced blastocysts continue to secrete boIFN $\tau$ in small amounts for a few days, they fail to attach to the culture dish and form outgrowths, and soon lose structural integrity (207). By contrast, when day 8 blastocysts are transferred to the uteri of synchronized cows, recovered 4 days later, and then cultured, they attach, form outgrowths, and begin to produce large amounts of boIFN $\tau$. Therefore, while the initiation of IFN $\tau$ expression may be developmentally regulated, some factor or factors in the luteal phase environment of the maternal uterus are conceivably required either for full expression of the IFN $\tau$ or to promote trophoblast growth and development, which in turn leads to increased IFN $\tau$ production. In this regard, it has been noted with both sheep (209) and cattle (210) that an advanced luteal phase results in accelerated conceptus development and earlier production of IFN $\tau$, and that simultaneous addition of two growth factors [insulin-like growth factor 1 (IGF-1) and IGF-2] to culture medium promotes increased synthesis of ovIFN $\tau$ (211).

The association between IFN $\tau$ expression and conceptus development is illustrated diagramatically in Fig. 3. It is intriguing that each major change in expression accompanies a significant restructuring of the conceptus. For example, initial expression is noted in association with the appearance of a definitive trophectoderm, full expression with the elongation of the blastocyst, and decline with the period of trophoblast attachment to the uterine wall. However, at present it is still not possible to determine whether IFN $\tau$ synthesis is coupled tightly to conceptus development or whether the two processes are controlled independently.

Measurements from cultured ovine conceptuses have indicated that at around day 15 to 16 of gestation a single conceptus can release more than $100 \mu \mathrm{g}$ IFN in $24 \mathrm{~h}(10$, 149) (Fig. 3). Since synthesis in culture is not linear and tails off markedly after $6-12 \mathrm{~h}$ (180), this value is probably an underestimate of quantities produced in the pregnant uterus. In relationship to DNA content, synthesis is highest between days 12 and 14 and then begins to decline markedly. These data are consistent with the experiments described earlier in which in situ hybridization was used to detect ovIFN $\tau$ mRNA $(200,201)$.

On initial scrutiny, the magnitude of IFN $\tau$ expression ( $>100 \mu$ g daily around days 15 to 16 ) seems far in excess of what would be required to saturate endometrial type I receptors, which, as noted earlier, have $K_{d}$ values around $10^{-11} \mathrm{M}$, i.e. they would be half-saturated with ovIFN $\tau$ at $0.2 \mathrm{ng} / \mathrm{ml}$. However, expression per cell rather than per conceptus (Fig. 3) is maximal about 3 days earlier when the first pulses of PGF are detectable in the nonpregnant ewe $(26,27)$. At this critical juncture, over- 
all production of ovIFN $\tau$ is low (probably $<1 \mu \mathrm{g} /$ day), yet still seems to be sufficient to be antiluteolytic. The apparent superfluity of ovIFN $\tau$ over the subsequent few days, when so much growth occurs, may be a vestige of this earlier very high cellular expression at days 12-13. Alternatively, the high production by elongated conceptuses may be necessary if the IFN $\tau$ has to diffuse to locations more distant than the uterine surface and glandular epithelium. In this regard, low amounts of antiviral activity ( $\sim 60$ international reference units/ml or $\sim 3 \mathrm{ng} /$ $\mathrm{ml}$ ) were consistently detected in the utero-ovarian veins (but not in the peripheral circulation) of pregnant ewes at day 15 after mating, and such activity was absent in nonmated controls (105).

\section{E. Features of $I F N \tau$ gene promoters}

1. The promoter dictates cell specificity. The discovery that JAR (150) and other human choriocarcinoma cells such as BeWo (212) support constitutive expression of IFN $\tau$ genes has allowed different promoter-reporter gene constructs to be tested for expression (150). These experiments have clearly revealed that the upstream region to position -126 from the transcription start site of the bovine IFN $\tau$ gene could increase expression of a human $\mathrm{GH}$ reporter gene 4- to 5 -fold relative to a promoterless control, and that sequences between -126 and -450 possessed additional enhancer activity. These results contrast with similar studies carried out with IFN $\alpha$ and $\operatorname{IFN} \beta$ genes where sequences upstream of about -120 appeared to be dispensable for conferring viral inducibility (Section IV.C).

Genomic sequences have now been reported for the IFN $\tau$ of cattle $(53,213)$, sheep $(52,192)$, goat $(192)$, and musk ox (192), all of which are related species within the Bovidae family. Like the genes of other known type I IFN, they lack introns as revealed by Southern blotting analysis. There are a minimum of four to five such genes in each of the above species, except the musk ox which has two. In addition to three genes that resemble known cDNA, one pseudogene (52) and a gene that codes for an ovIFN $\tau$ of 162 amino acids (192) have been described. The proximal promoter regions of all the genes are highly conserved both within and across species (Fig. 4), underscoring the likelihood that the unusual promoter organization of the IFN $\tau$ genes (see below) is an essential component of the tissue- and stage-specific patterns of their expression. Unlike other type I genes, which usually start to diverge markedly from each other beyond about 120 bases upstream of the transcription start site, sequence similarities in the IFN $\tau$ persist up to at least base position -400 both within and between species (see Ref. 192), suggesting that these more distal regions may be important for promoter regulation. Such predictions have, of course, been born out in the promotion-deletion studies discussed previously.

It has also been instructive to compare the promoter regions of the IFN $\tau$ genes with the sequences that comprise tissue-specific enhancer elements of the human CG $\alpha$-subunit $(\mathrm{CG} \alpha)$ (214) and placental lactogen (PL) (215) genes, both of which are expressed in human trophoblast cell lines. Enhancers for these genes have been defined that are both necessary and sufficient to direct cellspecific expression. Nevertheless, no sequences resembling either of these enhancer elements are found in the first $450 \mathrm{bp}$ of the IFN $\tau$ promoter. On the other hand, the $\mathrm{CG} \alpha$ and PL enhancers are themselves highly distinct and show no obvious resemblance to each other. Thus, comparisons of the trophoblast IFN, CG $\alpha$, and PL genes suggest that each is regulated independently. $\mathrm{CG} \alpha$ and PL genes are, in fact, not expressed coordinately in vivo. Rather, $\mathrm{CG} \alpha$ is produced much earlier in the development of the placenta than PL. Furthermore, CG $\alpha$ is expressed at an earlier stage of trophoblast cell differentiation than PL in vitro (216). Since the IFN $\tau$ genes are probably not present in primates (192), it is difficult to judge with any precision where such genes lie in a regulatory hierarchy compared to the other trophoblastspecific genes. Nonetheless, expression of the IFN $\tau$ genes begins at a relatively early stage of trophoblast differentiation in ruminant conceptuses and probably precedes at least one member of the PL family (217). In ruminants the PL-like hormones are synthesized by the binucleate cells, which are few in number at the time of maximal IFN $\tau$ expression (16). Again, these observations make it likely that factors that influence trophoblast cell differentiation are critically important determinants of trophoblast IFN transcription.

2. The trophoblast IFN promoter is functionally distinct from other type I IFN. Production of IFN by the early ovine and bovine conceptus is unparalleled in any other system. For example, on an equivalent cell basis, bovine conceptuses at day 18 of gestation released at least 300fold more IFN constitutively in culture than did leukocytes induced by virus (150). The difference between these IFN-producing systems appears to be due to some unique feature of IFN $\tau$ genes since at least $99 \%$ of the IFN secreted by the conceptuses is IFN $\tau$, while the mRNA of other type I IFN are present at levels roughly equivalent to those found in virus-induced leukocytes. These data support the conclusion that the IFN $\tau$ genes are specialized in their pattern of expression and suggest a basic difference between them and other type I IFN in the means by which transcription is regulated.

Whereas the boIFN $\tau$ promoter is active in JAR cells, the boIFN $\omega$ promoter is not (Section IV.D.1). Reporter gene activity is at least 100 - to 500 -fold higher when 


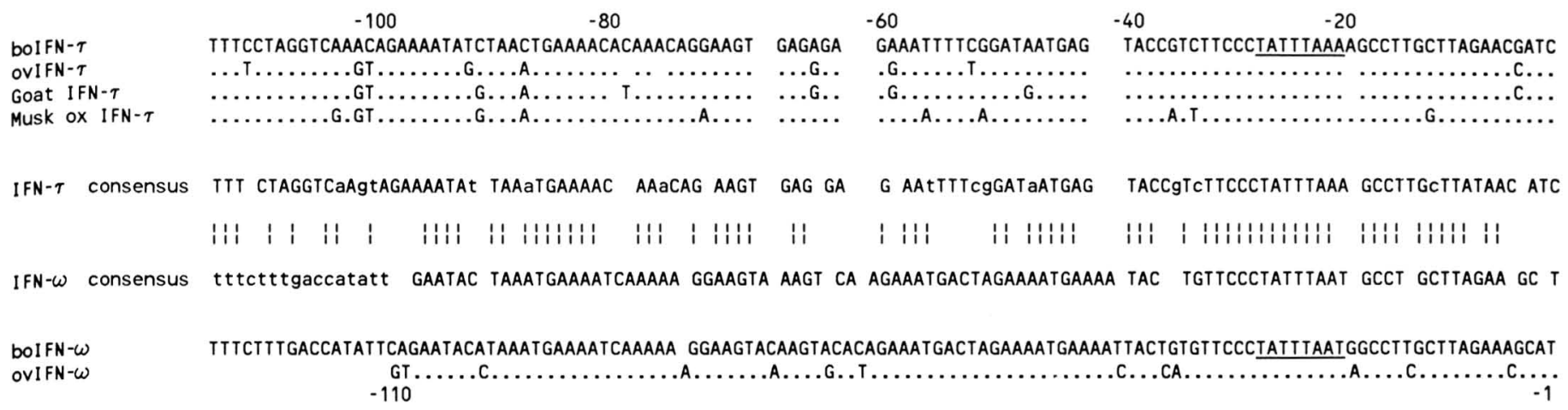

FIG. 4. Promoter sequence alignment of the genes for bovine, ovine, goat, and musk ox IFN $\tau$, and bovine and ovine IFN $\omega$. Sequences are compared over the first $\sim 110$ bases from the transcription start site with the TATA box underlined. The bases that are conserved between all promoters within either the IFN $\tau$ or IFN $\omega$ are indicated in capital letters in the consensus sequences. Those that are conserved in all but one gene promoter are shown in lower case letters. Sequence conservation between the two consensus sequences for IFN $\tau$ and IFN $\omega$ are notated by vertical lines. Gaps have been introduced to provide optimal sequence alignments. Data are from Hansen et al. (53) and Leaman et al. (192).

expression from approximately $450 \mathrm{bp}$ of IFN $\tau$ and IFN $\omega$ promoters is compared (150). Sequence comparisons among members of the type I IFN genes reveal a high degree of superficial similarity across all members, including the IFN $\tau$, within the proximal promoter region $(53,56,65,141,192)$ (Fig. 2). Hexameric repeats of the sequence GAAANN (where $\mathrm{N}$ is any nucleotide) or AAGTGA are prevalent in all genes, although the arrangement and numbers of such sequences, thought to confer responsiveness to virus induction, are different for each gene. Upstream of the relatively well conserved proximal promoter, the similarity of the IFN $\tau$ promoter to other type I IFN promoters decreases, as does the similarity among all type I IFN genes, including different loci of a single subtype (192). This observation is not unexpected since sequences upstream of approximately position -120 are dispensible for normal regulation of both IFN $\alpha$ (191) and - $\beta$ genes (181). As described earlier, the conservation of IFN $\tau$ gene sequences well upstream of the transcription start site seems to be an exception to this rule (192).

Although IFN $\tau$ genes possess promoter sequences which contain elements found in virus-inducible IFN genes (Fig. 2), they are only poorly responsive to virus or double-stranded RNA. Sendai virus stimulation of bovine leukocytes induced expression of IFN $\tau$ that was detectable only by reverse transcription-polymerase chain reaction but not by antiviral assay (150). Similarly, ovine conceptuses incubated with poly(I):poly(C) expressed IFN $\tau$ mRNA at levels only 2 -fold higher than controls (202). In addition, reporter gene constructs employing the IFN $\tau$ promoter were not detectably induced in transfected nontrophoblast cells (CHO and L929) by Newcastle's disease virus (J. C. Cross, unpublished data). As another test of the similarity between trophoblast and other type I IFN promoters, cells were cotransfected with various IFN promoter-reporter gene constructs and a plasmid which overexpressed the transcriptional activator IRF-1. As discussed earlier (Section IV.C), IRF-1 binds purine-rich hexamer sequences found commonly in all type I IFN promoters, and its overexpression transactivates endogenous IFN $\alpha,-\beta$, and $-\omega$ genes (185). When tested in CHO cells in which neither the IFN $\omega$ nor IFN $\tau$ promoters are active, IRF-1 increased expression from a bovine IFN $\omega$ promoter 3 - to 4 -fold, whereas it had no stimulatory effect on a boIFN $\tau$ promoter (218).

Together these data indicate that while IFN $\tau$ and other type I IFN promoters are quite similar at a sequence level, they are functionally distinct, a result that suggests that subtle differences in transcription factor binding sites have large overall effects on transcription. The organization of the "mini-enhancer" elements thought to comprise the viral responsive element appear to be distinct in the IFN $\tau$ compared to other known type I genes (see Refs. 53 and 192 for discussion) (Fig. 2). In particular, even though they are present, there is no clustering of GAAANN sequences or AAATGA and related motifs that bind the transcription factor IRF-1 into structures resembling well defined viral response elements, and it is probably for this reason that the genes are so poorly inducible by virus. In addition, there are no $\mathrm{NF}-\kappa \mathrm{B}$ binding sites, and no motifs indicative of possible cAMP or phorbol ester responsiveness.

\section{The Uniqueness of the IFN $\tau$}

\section{A. Evolution of the IFN $\tau$ genes and their restricted distribution in mammals}

The type I IFN are thought to have evolved from a common ancestral gene before the time of mammalian divergence $(56,70)$. Sequence similarities among the type I IFN suggest that these genes continued to evolve as depicted in Fig. 5. Note that after the divergence of the IFN $\beta$ from IFN, the IFN $\alpha$ prototypic gene became ex- 


\section{EVOLUTION OF INTERFERONS}

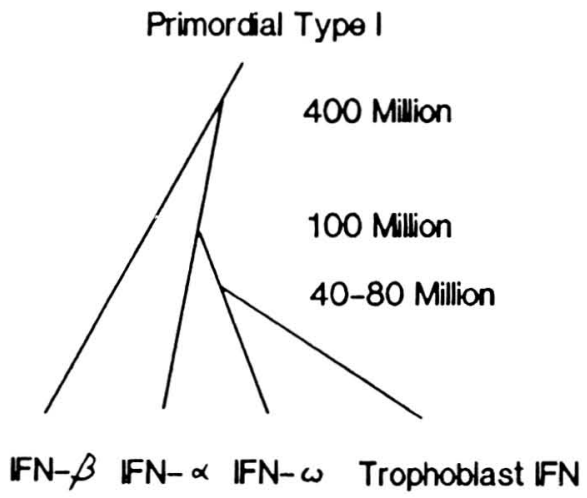

Primordal Type ॥

FN $-\beta$ IFN $-\alpha$ IFN $-\omega$ Trophoblast IFN

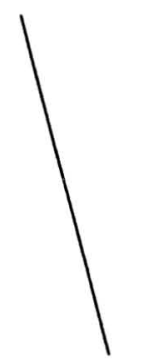

IFN- $\gamma$

All Mammals $^{*}$ - Ruminants -

All Mammals

FIG. 5. A diagram showing the probable temporal sequence divergence of the various type I IFN subtypes $(\alpha, \beta, \omega$, and $\tau)$ from a single precursor gene. The IFN $\tau$ probably arose from the IFN $\omega$ about 60 million years ago. All the subtypes in cattle are represented by multiple genes (not shown). ${ }^{*}$, IFN $\omega$ genes have not been identified in several species including the dog and mouse.

tensively amplified. The IFN $\omega$ genes are more closely related to the IFN $\alpha$ than IFN $\beta$ and most likely diverged from them somewhat later in evolution.

Genomic Southern blot experiments with cDNA probes designed to hybridize to IFN $\tau$ but not to related IFN $\omega$ genes have indicated the apparent absence of IFN $\tau$ in all species except the large ruminants, e.g. the Bovidae mentioned above, gazelle, deer, and giraffe (192). By contrast, the genes for IFN $\alpha$ and $-\beta$ have been found in all mammalian species where they have been sought (56, 67 ), although the number for both types varies widely from species to species. The IFN $\omega$ are also represented in most mammals [notable exceptions being dog and rodents $(192,219)]$, usually as multiple gene copies (53, $63,155,192,220)$. Certain species that are closely related evolutionarily to ruminants possess IFN $\omega$ genes (155) but apparently lack IFN $\tau$ (192). For example, the pig and hippopotamus (Suina suborder) and the llama ( $T y$ lopoda suborder) are within the order Artiodactyla and may have diverged from the Ruminantia suborder as recently as 55 to 60 million years ago (221). Similarly, the horse and zebra, which also lack IFN $\tau$ genes, are members of the order Perissodactyla, that may have separated from the Artiodactyla as recently as 65 million years ago (221), although other authorities suggest a more ancient divergence (222). It may also be significant that the giraffe, which diverged from the cattle and sheep an estimated 30 million years ago, gave a single hybridizing band on Southern blots, while the Bovidae all possessed multiple genes (192). These data together suggest that the IFN $\tau$ must have diverged from the IFN $\omega$ within the last 65 million years and duplicated several times to their present numbers in domestic ruminants quite recently. It is interesting that the amplification of IFN $\beta$ genes, which are also represented by multiple copies in the ungulates but not, as far as is known, in most other species $(56,65,67)$, may have gone hand in hand with the evolution of the IFN $\tau$. Since all the type I IFN genes, including those from cattle (223), are invariably clustered together on the same chromosome, it will be intriguing to determine their relative map positions since this information may provide a clue as to how the gene duplication events occurred. Direct sequence comparisons to determine more precisely when IFN $\tau$ divergence occurred and from which member of the IFN $\omega$ these genes evolved will have to await a detailed analysis of all potential trophoblast IFN and IFN $\omega$ genes within a potential link species such as the giraffe.

Why should the IFN $\tau$ genes be restricted to the $A r$ tiodactyls? As discussed earlier, IFN production by ruminant conceptuses during the peri-implantation period is unparalleled among other mammalian species. Nonetheless, it is also clear that only the ruminant species appear to utilize an IFN as the initiator of maternal recognition of pregnancy. Thus, while most or all species produce some form of IFN possibly as a consequence of the development of the trophoblast from the inner cell mass, it could be argued that only the ruminant species have co-opted an IFN (and also one that is produced constitutively) to ensure the establishment of pregnancy. This difference has perhaps to do with the widely variant forms of placentation among the mammalian species and suggests that the evolution of the IFN $\tau$ genes was coincident with the evolution of the syndesmochorial placentation form utilized by ruminants.

\section{B. The IFN $\tau$ are a structurally distinct type I IFN subtype}

As discussed in Section II.C, although the IFN $\tau$ show structural similarity to other type I IFN, the extent of their amino acid sequence identity to the subtype they most resemble, the IFN $\omega$, is only about $70 \%$. In fact bovine, ovine, and caprine IFN $\tau$ are more similar to each other in sequence than boIFN $\tau$ is to boIFN $\omega$, and all evidence to date suggests they may constitute a serologically distinct group. Cross-species conservation of cDNA nucleotide sequence is also particularly high in the untranslated $5^{\prime}$ and $3^{\prime}$ segments of IFN $\tau$ transcripts, and the latter can be used as a highly specific probe for IFN $\tau$ mRNA and genes $(53,192,200-202)$. When genomic sequences are compared, the promoter regions of the bovine, caprine, ovine, and musk ox are almost completely conserved (Fig. 4) (192).

The above structural information, combined with other unusual features of the IFN $\tau$, e.g. their poor indu- 
cibility by virus (Section IV.E), the magnitude of their production, and the trophoblast-specific nature of their expression (Section IV.D) provide a persuasive case for classifying the IFN $\tau$ separately from the IFN $\omega$. This separation is consistent with the evolutionary data presented in Section V.A and the general rules of nomenclature that have previously been applied to IFN (56). It would not be surprising if yet other subtypes emerge in view of the numerous bands that hybridize to full-length IFN $\omega$ probes on Southern blots of bovine and ovine genomic DNA $(50,53,192)$. Conceivably some of these as yet undefined genes either represent evolutionary intermediates between the $\operatorname{IFN} \omega$ and $\operatorname{IFN} \tau$ or new branches of IFN divergence.

\section{Do the IFN $\tau$ have unique properties?}

The above question has been alluded to earlier (Section III.B) but is worth reconsidering in this concluding paragraph, since it is central to much of the current debate concerning the function of the IFN $\tau$ during pregnancy. Most evidence is consistent with the view that the IFN $\tau$ do not differ greatly from other type I IFN in structure or in the majority of their biological properties. They probably also bind to a common type I receptor subunit in the receptor complex, although the possibility of unique accessory subunits certainly exists. The only well authenticated difference regards effects of an IFN $\tau$ $v s$. boIFN $\alpha$ on estrous cycle length after the reagents are infused into the uterine horns of nonpregnant animals and where responses appear to be much greater to ovIFN $\tau$ than to boIFN $\alpha$ (Section III.B). The reason why IFN $\tau$ is more potent than IFN $\alpha$ is unclear but may relate to the slight differences in binding properties noted for the endometrial receptor complex $(118,119)$ or even to the apparently higher cytotoxicity of IFN- $\alpha$ (83). Tenfold or greater differences in efficacy in such processes as antiviral or antiproliferative activity are well documented among individual IFN $\alpha$ subtypes $(56,85)$, although it remains controversial as to whether all such potency differences can be attributed to relative affinitybinding constants for the receptor. Once more appropriate IFN reagents are utilized for comparative studies, e.g. recombinant ovIFN $\alpha$ for studies on sheep and boIFN $\tau$ on cattle, the issue may become properly resolved. An alternative explanation, of course, is that the IFN $\tau$ intervene in maternal recognition of pregnancy solely by virtue of their massive production in trophoblast at a particularly critical stage of gestation.

\section{Acknowledgements}

We are grateful to Gail Foristal for preparing the manuscript and to Drs. P. J. Hansen and W. T. Thatcher (University of Florida), F. Lefèvre, J. Martal [Institut National de la Recherche Agronomique
(INRA), Jouy en Josas, France] and T. Maniatis (Harvard University) for providing material not available to the authors at the time of writing. We also thank members of the Roberts' laboratory for helpful discussion and suggestions.

\section{References}

1. Roberts RM 1989 Minireview: conceptus interferons and maternal recognition of pregnancy. Biol Reprod 40:449

2. Roberts RM 1989 Minireview: a novel group of interferons associated with the early ovine and bovine embryo. J Interferon Res 9:373

3. Roberts RM, Farin CE, Cross JC 1990 Trophoblast proteins and maternal recognition of pregnancy. In: Milligan SR (ed) Oxford Reviews of Reproductive Biology. Oxford, U.K., Oxford University Press, vol 12:147-180

4. Roberts RM, Malathy PV, Hansen TR, Farin CE, Imakawa K 1990 Bovine conceptus products involved in pregnancy recognition. J Anim Sci 68 [Suppl 2]:28

5. Flint APF, Parkinson TJ, Stewart HJ, Vallet JL, Lamming GE 1991 Molecular biology of trophoblast interferons and studies of their effects in vivo. J Reprod Fertil [Suppl] 43:13

6. Martal J, Assal A, Assal E, Charlier M, Chene N, Charpigny G, Guillomot M, Chaouat G 1991 Characterization, antiluteolytic and immunosuppressive effects of ovine trophoblastin (oTP, $\alpha$ interferon of class "III"). In: Chaouat G, Mowbray J (eds) Cellular and Molecular Biology of the Materno-Fetal Relationship. Colloque INSERM/John Libbey Eurotext Ltd., London, vol 212:317324

7. Roberts RM 1991 A role for interferons in early pregnancy. BioEssays 13:121

8. Roberts RM, Klemann SW, Leaman DW, Bixby JA, Cross JC, Farin CE, Imakawa K, Hansen TR 1991 The polypeptides and genes for ovine and bovine trophoblast protein-1. J Reprod Fertil [Suppl] 43:3

9. Martal J, Chene N 1992 Function of embryonic interferons and of the main serum proteins specific for pregnancy. Trophoblast Res, in press

10. Roberts RM, Cross JC, Leaman DW 1992 Unique features of the trophoblast interferons. Pharmacol Ther 51:329

11. McClaren A 1982 The embryo. In: Austin CR, Short RV (eds) Reproduction in Mammals: 2 Embryonic and Fetal Development. Cambridge University Press, Cambridge, pp 1-25

12. Stevens DH 1983 Interspecies differences in the structure and function of trophoblast. In: Loke C, Whyte A (eds) Biology of Trophoblast. Elsevier, London, pp 111

13. Guillomot M, Flechon JE, Wintenberger-Torres S 1981 Conceptus attachment in the ewe: an ultrastructural study. Placenta 2:169

14. Bjorkman HH 1969 Light and electron microscopic studies on alteration in the normal bovine placentome. Anat Rec 163:17

15. Wooding FBF 1983 Frequency and localization of binucleate cells in the placentomes of ruminants. Placenta 4:527

16. Wooding FBP 1981 Localization of ovine placental lactogen in sheep placentomes by electron microscope immunocytochemistry. J Reprod Fertil 62:15

17. Short RV 1969 Implantation and the maternal recognition of pregnancy. In: Wolstenholme GEW, O'Connor M (eds) Foetal Autonomy: Ciba Foundation Symposium. J \& A Churchill Ltd. London, pp 2-26

18. Wilmut I, Sales DI, Ashworth CJ 1986 Maternal and embryonic factors associated with prenatal loss in mammals. J Reprod Fertil $76: 851$

19. Roberts RM, Schalue-Francis T, Francis H, Keisler D $1990 \mathrm{Ma}$ ternal recognition of pregnancy and embryonic loss. Theriogenology $33: 175$

20. Hearn JP, Webley GE, Gidley-Baird AA 1991 Chorionic gonadotrophin and embryo-maternal recognition during the peri-implantation period in primates. J Reprod Fertil 92:497

21. Lenton EA, Neal LM, Sulaiman R 1982 Plasma concentrations of human chorionic gonadotrophin from the time of implantation until the second week of pregnancy. Fertil Steril 37:773 
22. Hodgen GD, Itskovitz J 1988 Recognition and maintenance of pregnancy. In: Knobil E, Neill J (eds) The Physiology of Reproduction. Raven Press, New York, pp 1995-2021

23. McCracken JA, Schramm W, Okulicz WC 1984 Hormone receptor control of pulsatile secretion of $\mathrm{PGF}_{2 \ltimes}$ from the ovine uterus during luteolysis and its abrogation in early pregnancy. Anim Reprod Sci 7:31

24. Thatcher WW, Bazer FW, Sharp DC, Roberts RM 1986 Interrelationships between uterus and conceptus to maintain corpus luteum function in early pregnancy: sheep, cattle, pigs and horses. J Anim Sci 62 [Suppl II]:25

25. Bazer FW, Vallet JL, Roberts RM, Sharp DC, Thatcher WW 1986 Role of conceptus secretory products in establishment of pregnancy. J Reprod Fertil 76:841

26. Bazer FW, Thatcher WW, Hansen PJ, Mirando MA, Ott TL, Plante C 1991 Physiological mechanisms of pregnancy recognition in ruminants. J Reprod Fertil [Suppl] 43:39

27. Silvia WJ, Lewis GS, McCracken JA, Thatcher WW, Wilson L 1991 Review: hormonal regulation of uterine secretion of prostaglandin $\mathbf{F}_{2 \alpha}$ during luteolysis in ruminants. Biol Reprod 45:655

28. Godkin JD, Bazer FW, Moffatt J, Sessions F, Roberts RM 1982 Purification and properties of a major, low molecular weight protein releasted by the trophoblast of sheep blastocysts at day 13-21. J Reprod Fertil 65:141

29. Godkin JD, Bazer FW, Roberts RM 1984 Ovine trophoblast protein-1, an early secreted blastocyst protein, binds specifically to uterine endometrium and affects protein synthesis. Endocrinology 114:120

30. Martal J, Lacroix MC, Loudes C, Saunier M, WintenbergerTorres S 1979 Trophoblastin, an anti-luteolytic protein present in early pregnancy in sheep. J Reprod Fertil 56:63

31. Bartol FF, Roberts RM, Bazer FW, Lewis GS, Godkin JD, Thatcher WW 1985 Characterization of proteins produced in vitro by peri-attachment bovine conceptuses. Biol Reprod 32:681

32. Helmer SD, Hansen PJ, Anthony RV, Thatcher WW, Bazer FW, Roberts RM 1987 Identification of bovine trophoblast protein-1, a secretory protein immunologically related to ovine trophoblast protein-1. J Reprod Fertil 79:83

33. Anthony RV, Helmer SD, Sharif SF, Roberts RM, Hansen PJ, Thatcher WW, Bazer FW 1988 Synthesis and processing of ovine trophoblast protein-1 and bovine trophoblast protein-1, conceptus secretory proteins involved in the maternal recognition of pregnancy. Endocrinology 123:1274

34. Helmer SD, Hansen PJ, Thatcher WW 1988 Differential glycosylation of the components of the bovine trophoblast protein-1 complex. Mol Cell Endocrinol 58:103

35. Godkin JD, Bazer FW, Thatcher WW, Roberts RM 1984 Proteins released by cultured day $15-16$ conceptuses prolong luteal maintenance when introduced into the uterine lumen of cyclic ewes. $J$ Reprod Fertil 71:57

36. Vallet JL, Bazer FW, Fliss MFV, Thatcher WW 1988 Effect of ovine conceptus secretory proteins and purified ovine trophoblast protein-1 on interoestrous interval and plasma concentrations of prostaglandin $\mathrm{F}_{2 \alpha}$ and $\mathrm{E}$ and of 13,14-dihydro-15-keto prostaglandin $\mathrm{F}_{2 \alpha}$ in cyclic ewes. J Reprod Fertil 84:493

37. Fincher KB, Bazer FW, Hansen PJ, Thatcher WW, Roberts RM 1986 Ovine conceptus secretory proteins suppress induction of uterine prostaglandin $\mathrm{F}_{2 \alpha}$ release by oestradiol and oxytocin. $\mathrm{J}$ Reprod Fertil 76:425

38. Gnatek GG, Smith LD, Duby RT, Godkin JD 1989 Maternal recognition of pregnancy in the goat: effects of conceptus removal on interestrus intervals and characterization of conceptus protein production during early pregnancy. Biol Reprod 41:655

39. Baumbach GA, Duby RT, Godkin JD 1990 N-Glycosylated and unglycosylated forms of caprine trophoblast protein-1 are secreted by preimplantation goat conceptuses. Biochem Biophys Res Commun 172:16

40. Zarco L, Stabenfeldt GH, Basu S, Bradford GE, Kindahl H 1988 Modification of prostaglandin $\mathrm{F}_{2 \alpha}$ synthesis and release in the ewe during the initial establishment of pregnancy. J Reprod Fertil 83:527

41. Zarco L, Stabenfeldt GH, Quicke JF, Kindahl H, Bradford GE
1988 Release of prostaglandin $\mathrm{F}$ and the timing of events associated with luteolysis in ewes with oestrous cycles of different lengths. J Reprod Fertil 83:517

42. Peterson AJ, Tervit HR, Fairclough RJ, Havik PG, Smith JF 1976 Jugular levels of 13,14-dihydro-15-keto-prostaglandin F and prosgesterone around luteolysis and early pregnancy in the ewe. Prostaglandins 12:551

43. Wiltbank MC, Wiepz GJ, Knickerbocker JJ, Belfiore CJ, Niswender GD 1992 Proteins secreted from the early ovine conceptus block the action of prostaglandin $\mathrm{F}_{2 \alpha}$ on large luteal cells. Biol Reprod 46:475

44. Niswender GD, Nett TM 1988 The corpus luteum and its control. In: Knobil E, Neill J (eds) The Physiology of Reproduction. Raven Press, New York, pp 489-525

45. Imakawa K, Anthony RV, Kazemi M, Marotti KR, Polites HG, Roberts RM 1987 Interferon-like sequence of ovine trophoblast protein secreted by embryonic trophectoderm. Nature 330:377

46. Imakawa K, Hansen TR, Malathy P-V, Anthony RV, Polites HG, Marotti KR, Roberts RM 1989 Molecular cloning and characterization of complementary deoxyribonucleic acids corresponding to bovine trophoblast protein-1: a comparison with ovine trophoblast protein-1 and bovine interferon- $\alpha_{\mathrm{II}}$. Mol Endocrinol 3:127

47. Stewart HJ, McCann SHE, Barker PJ, Lee KE, Lamming GE, Flint APF 1987 Interferon sequence homology and receptor binding activity of ovine trophoblast antiluteolytic protein. J Endocrinol 115:R13

48. Charpigny G, Reinaud P, Huet J-C, Guillomot M, Charlier M, Pernollet J-C, Martal J 1988 High homology between a trophoblast protein (trophoblastin) isolated from ovine embryo and $\alpha$ interferons. FEBS Lett 228:12

49. Charlier M, Hue D, Martal J, Gaye P, 1989 Cloning and expression of cDNA encoding ovine trophoblastin: its identity with a class II alpha interferon. Gene 77:341

50. Stewart HJ, McCann SHE, Northrop AJ, Lamming GE, Flint APF 1989 Sheep antiluteolytic interferon: cDNA sequence and analysis of mRNA levels. J Mol Endocrinol 2:65

51. Klemann SW, Imakawa K, Roberts RM 1990 Sequence variability among ovine trophoblast interferon mRNA. Nucleic Acids Res 18:6724

52. Charlier M, Hue D, Boisnard M, Martal J, Gaye P 1991 Cloning and structural analysis of two distinct families of ovine interferon$\alpha$ genes encoding functional class II and trophoblast (oTP-1) $\alpha$ interferons. Mol Cell Endocrinol 76:161

53. Hansen TR, Leaman DW, Cross JC, Mathialagan N, Bixby JA, Roberts RM 1991 The genes for the trophoblast interferons and the related interferon- $\alpha_{\text {II }}$ possess distinct 5-promoter and 3-flanking sequences. J Biol Chem 266:3060

54. Watkins SP, Jeacock MK, Savva D, Shepherd DAL 1991 Ovine trophoblast protein-one: evidence for possible glycosylation. Int J Biochem 23:1013

55. Isaacs A, Lindenman J 1957 Virus interference. I. The interferon. Proc R Soc Lond (Biol) 147:258

56. DeMaeyer E, DeMaeyer-Guignard J 1988 Interferons and Other Regulatory Cytokines. John Wiley \& Sons, New York

57. Rossi GB 1985 Interferons and Cell Differentiation. In: Gresser I (ed), Interferon 6. Academic Press, London, pp 31-68

58. Tamm I, Lin SL, Pffeffer LM, Sehgal PB 1987 Interferons $\alpha$ and $\beta$ as cellular regulatory molecules. In: Gresser I (ed) Interferon 9. Academic Press, London, pp 13-73

59. Chard T 1991 Commentary: nterferon- $\alpha$ is a reproductive hormone. J Endocrinol 131:337

60. LaBonnardiere C, Martinat-Botte F, Terqui M, Lefevre F, Zourari K, Martal J, Bazer FW 1991 Production of two species of interferon by large white and Meischan pig conceptuses during the peri-attachment period. J Reprod Fertil 91:469

61. Lefevre F, Martinat-Botte F, Guillomot M, Zouari K, Charley B, LaBonnardiere C 1990 Interferon- $\gamma$ gene and protein are spontaneously expressed by the porcine trophectoderm early in gestation. Eur J Immunol 20:2485

62. Ijzermans JNM, Marquet RL 1989 Interferon gamma: a review. Immunology 179:456

63. Capon DJ, Shepard HM, Goeddel DV 1985 Two distinct families 
of human and bovine interferon- $\alpha$ genes are coordinately expressed and encode functional polypeptides. Mol Cell Biol 5:768

64. Hauptmann R, Swetly P 1985 A novel class of human type 1 interferons. Nucleic Acids Res 13:4739

65. Weissmann C, Weber H 1986 The interferon genes. Prog Nucleic Acid Res Mol Biol 33:251

66. Adolf GR 1987 Antigenic structure of human interferon- $\omega 1$ (interferon- $\left.\alpha_{\mathrm{II}} 1\right)$ : comparison with other human interferons. J Gen Virol 68:1669

67. Wilson V, Jeffreys AJ, Barrie PA, Boseley PG, Slocombe PM, Easton A, Burke DC 1983 A comparison of vertebrate interferon gene families detected by hybridization with human interferon DNA. J Mol Biol 166:457

68. Adolf GR, Maurer-Fogy I, Kalsner I, Cantell K 1990 Purification and characterization of natural human interferon w-1. Two alternative cleavage sites for the signal peptidase. J Biol Chem 265:9290

69. Wetzel R 1981 Assignment of the disulfide bonds of leukocyte interferon. Nature 289:606

70. Gillespie D, Pequignot E, Carter WE 1984 Evolution of interferon genes. In: Carne PE, Carter WA (eds) Handbook of Experimental Pharmacology. Springer-Verlag, New York, vol 71:45-70

71. Zav'yalov VP, Denesyuk AI, Zav'yalova GA 1990 Theoretical conformational analysis of a family of $\alpha$-helical immunocytokines. Biochim Biophys Acta 1041:178

72. Zav'yalov VP, Denesyuk AI, Zav'yalova GA 1989 Theoretical analysis of conformation and active sites of interferons. Immunol Lett 22:173

73. Zoon KC, Wetzel R 1984 Comparative structures of mammalian interferons. In: Carne PE, Carter WA (eds) Handbook of Experimental Pharmacology. Springer-Verlag, New York, vol 71:79100

74. Matsuda S, Senda T, Itoh S, Kawano G, Mizuno H, Mitsui Y 1989 New crystal form of recombinant murine interferon- $\beta$. J Biol Chem 264:13381

75. Senda T, Matsuda S, Kawano G, Shimizu H, Nakamura KT, Mitsui Y 1990 Crystal structure analysis of recombinant murine interferon- $\beta$ at $2.6 \AA$ resolution. J Interferon Res 10 [Suppl]): Abstract 119

76. Klemann SW, Li J, Imakawa K, Cross JC, Francis H, Roberts RM 1990 The production, purification and bioactivity of bovine trophoblast protein-1 (bovine trophoblast interferon). Mol Endocrinol 4:1506

77. Pontzer CH, Torres BA, Vallet JL, Bazer FW, Johnson HM 1988 Antiviral activity of the pregnancy recognition hormone ovine trophoblast protein-1. Biochem Biophys Res Commun 152:801

78. Roberts RM, Imakawa K, Niwano Y, Kazemi M, Malathy PV, Hansen TR, Glass AA, Kronenberg LH 1989 Interferon Production by the preimplantation sheep embryo. J Interferon Res 9:175

79. Martal J, Degryse E, Charpigny G, Assal N, Reinaud P, Charlier M, Gaye P, Lecocq JP 1990 Evidence for extended maintenance of the corpus luteum by uterine infusion of a recombinant $\alpha$ interferon (trophoblastin) in sheep. J Endocrinol 127:R5

80. Cerutti M, Hue D, Charlier M, L'Haridon R, Pernollet J-C, Devauchelle G, Gaye P 1991 Expression of a biologically active ovine trophoblastic interferon using a baculovirus expression system. Biochem Biophys Res Commun 181:443

81. Ott TL, Vanheeke G, Johnson HM, Bazer FW 1991 Cloning and expression in Saccharomyces-cerevisiae of a synthetic gene for the type I trophoblast interferon, ovine trophoblast protein-1: purification and antiviral activity. J Interferon Res 11:357

82. Plante C, Hansen PJ, Thatcher WW, Johnson JW, Pollard JW, Mirando MA, Bazer FW 1990 Purification of bovine trophoblast1 complex and quantification of its microheterogeneous variants as affected by culture conditions. J Reprod Immunol 18:271

83. Pontzer CH, Bazer FW, Johnson HM 1991 Antiproliferative activity of a pregnancy recognition hormone, ovine trophoblast protein-1. Cancer Res 51:5304

84. Bazer FW, Johnson HM 1991 Type I conceptus interferons: maternal recognition of pregnancy signals and potential therapeutic agents. Am J Reprod Immunol 26:19
85. Fintner N 1991 Why are there so many subtypes of alphainterferons? J Interferon Res Special Issue, Jan 1991, p 185

86. Niwano Y, Hansen TR, Kazemi M, Malathy P-V, Johnson HD, Roberts RM, Imakawa K 1989 Suppression of T-lymphocyte blastogenesis by ovine trophoblast protein-1 and human interferon- $\alpha$ may be independent of interleukin-2 production. Am J Reprod Immunol 20:21

87. Newton CR, Vallet JL, Hansen PJ, Bazer FW 1989 Inhibition of lymphocyte proliferation by ovine trophoblast protein-1 and a high molecular weight glycoprotein produced by the peri-implantation sheep conceptus. Am J Reprod Immunol 19:99

88. Fillion C, Chaouat G, Reinaud P, Charpigny JC, Martal J 1991 Immunoregulatory effects of ovine trophoblastin protein (oTP): all five isoforms suppress PHA-induced lymphocyte proliferation. J Reprod Immunol 19:237

89. Skopets B, Li J, Thatcher WW, Roberts RM, Hansen PJ 1992 Inhibition of lymphocyte proliferation by bovine trophoblast protein-1 (type I trophoblast interferon) and bovine interferon- $\alpha 1$. Vet Immunol Immunopathol, in press

90. Short EC, Geisert RD, Helmer SD, Zavy MT, Fulton RW 1991 Expression of antiviral activity and induction of 2,5-oligoadenylate synthetase by conceptus secretory proteins enriched in bovine trophoblast protein-1. Biol Reprod 44:261

91. Barros CM, Plante C, Thatcher WW, Hansen PJ 1991 Regulation of bovine endometrial secretion of prostaglandins and synthesis of 2,5-oligoadenylate synthetase by interferon- $\alpha$ molecules. Am J Reprod Immunol 25:146

92. Mirando MA, Short EC Jr Geisert RD, Vallet JL, Bazer FW 1991 Stimulation of 2,5-oligoadenylate synthetase activity in sheep endometrium during pregnancy, by intrauterine infusion of oTP 1 , and by intramuscular administration of recombinant bovine interferon- $\alpha_{\mathrm{I}} 1$. J Reprod Fertil 93:599

93. Vallet JL, Bazer FW, Roberts RM 1987 The effect of ovine trophoblast protein-1 on endometrial protein secretion and cyclic nucleotides. Biol Reprod 37:1307

94. Francis H, Keisler DH, Roberts RM 1991 Induction of the synthesis of the pregnancy-specific protein $\mathrm{p} 70$ in the endometrium by intramuscular injection of recombinant bovine interferon- $\alpha_{1} 1$ in nonpregnant ewes. J Reprod Fertil 93:367

95. Salamonsen LA, Stuchbery SJ, O'Grady CH, Godkin JD, Findlay JK 1988 Interferon- $\alpha$ mimics effects of ovine trophoblast protein1 on prostaglandin and protein secretion by ovine endometrial cells in vitro. J Endocrinol 117:R1

96. Sharif SF, Francis H, Keisler DH, Roberts RM 1989 Correlation between the release of ovine trophoblast protein-1 by the conceptus and the production of polypeptides by the maternal endometrium of ewes. J Reprod Fertil 85:471

97. Ott TL, Van Heeke G, Fliss FMV, Johnson HM, Bazer FW 1991 Antiluteolytic and antiviral activities of recombinant ovine trophoblast protein-1 overproduced from a synthetic gene in $S$. cerevisiae. Biol Reprod 44:obSuppl 1]:89 (Abstract)

98. Knickerbocker JJ, Thatcher WW, Bazer FW, Drost M, Barron DH, Fincher KB, Roberts RM 1986 Proteins secreted by day 16 to 18 bovine conceptuses extend corpus luteum function in cows. J Reprod Fertil 77:381

99. Helmer SD, Hansen PJ, Thatcher WW, Johnson JW, Bazer FW 1989 Intrauterine infusion of highly enriched bovine trophoblast protein-1 complex exerts an antiluteolytic effect to extend corpus luteum lifespan in cyclic cattle. J Reprod Fertil 87:89

100. Stewart HJ, McCann SHE, Lamming GE, Flint APF 1989 Evidence for a role for interferon in the maternal recognition of pregnancy. J Reprod Fertil [Suppl] 37:127

101. Plante C, Hansen PJ, Thatcher WW 1988 Prolongation of luteal lifespan in cows by intrauterine infusion of recombinant bovine $\alpha$-interferon. J Endocrinol 122:2342

102. Plante C, Hansen PJ, Martinod S, Siegenthaler B, Thatcher WW, Leslie MV 1989 Effect of intrauterine and intramuscular administration of recombinant bovine interferon $\alpha 1$ on luteal lifespan in cattle. J Dairy Sci 72:1859

103. Plante C ,Thatcher WW, Hansen PJ 1991 Alteration of oestrous cycle length, ovarian function and oxytocin-induced release of prostaglandin $\mathrm{F}_{2 \alpha}$ by intrauterine and intramuscular administra- 
tion of recombinant bovine interferon- $\alpha$ to cows. J Reprod Fertil 93:375

104. Nephew KP, McLure KE, Day ML, Xie S, Roberts RM, Pope WF 1990 Effects of intramuscular administration of recombinant bovine interferon- $\alpha_{1} 1$ during the period of maternal recognition of pregnancy. J Anim Sci 68:2766

105. Schalue-Francis TK, Farin PW, Cross JC, Keisler D, Roberts RM 1991 Effect of injected bovine interferon- $\alpha_{1} 1$ on oestrous cycle length and pregnancy success in sheep. J Reprod Fertil 91:347

106. Martinod S, Maurer RR, Siegenthaler B, Gerber C, Hansen PJ 1991 The effects of recombinant bovine interferon- $\alpha$ on fertility in ewes. Theriogenology 36:231

107. Newton GR, Martinod S, Hansen PJ, Thatcher WW, Siegenthaler B, Gerber C, Voirol M-J 1990 Bovine interferon causes acute changes in body temperature and serum concentrations in heifers. J Dairy Sci 73:3439

108. Barros CM, Newton GR, Thatcher WW, Drost M, Plante C, Hansen PJ 1992 The effect of bovine interferon- $\alpha \mathrm{I} 1$ on pregnancy in heifers. J Anim Sci 70, in press

109. Stinnakre MG, Vilotte JL, Soulier S, L'Haridon R, Charlier M, Gaye P, Mercier JC 1991 The bovine $\alpha$-lactalbumin promoter directs expression of ovine trophoblast interferon in the mmary gland of transgenic mice. FEBS Lett 284:19

110. Knickerbocker JJ, Thatcher WW, Bazer FW, Barron DH, Roberts $\mathrm{RM} 1986$ Inhibition of uterine prostaglandin $\mathrm{F}_{2 \mathrm{z}}$ a production by bovine conceptus secretory proteins. Prostaglandins 31:777

111. Salamonsen LA, Manikhot J, Healy DL, Findlay JK 1989 Ovine trophoblast protein-1 and human interferon alpha reduce prostaglandin synthesis by ovine endometrial cells. Prostaglandins 38:289

112. Helmer SD, Gross TS, Hansen PJ, Thatcher WW 1989 Bovine trophoblast protein-1 complex alters endometrial protein and prostaglandin secretion and induces an intracellular inhibitor of prostaglandin synthesis in vitro. J Reprod Fertil 87:421

113. Gross TS, Plante C, Thatcher WW, Hansen PJ, Helmer SD, Putney DJ 1988 Secretory proteins of the bovine conceptus alter prostaglandin and protein secretion in vitro. Biol Reprod 39:977

114. Thatcher WW, Hansen PJ, Gross TS, Helmer SD, Plante C, Bazer FW 1989 Antiluteolytic effects of bovine trophoblast protein-1. J Reprod Fertil [Suppl] 37:91

115. Flint APF, Sheldrick EL, McCann TJ, Jones DSC 1990 Luteal oxytocin: characteristics and control of synchronous episodes of oxytocin and $\mathrm{PGF}_{2 \mathrm{Z}}$ a secretion at luteolysis in ruminants. Domest Anim Endocrinol 7:111

116. Mirando MA, Ott TL, Harney JP, Bazer FW 1990 Ovine trophoblast protein-one inhibits development of endometrial responsiveness to oxytocin in ewes. Biol Reprod 43:1070

117. Vallet JL, Lamming GE 1991 Ovine conceptus secretory proteins and bovine recombinant interferon $\alpha_{\mathrm{I}}-1$ decrease endometrial oxytocin receptor concentrations in cyclic and progesteronetreated ovariectomized ewes. J Endocrinol 131:475

118. Hansen TR, Kazemi M, Keisler DH, Malathy PV, Imakawa K, Roberts RM 1989 Complex binding of the embryonic interferon, ovine trophoblast protein-1, to endometrial receptors. J Interferon Res 9:215

119. Knickerbocker JJ, Niswender GD 1989 Characterization of endometrial receptors for ovine trophoblast protein-1 during the estrous cycle and early pregnancy in sheep. Biol Reprod 40:361

12.0. Rubinstein M, Orchansky R 1986 The interferon receptors. CRC Crit Rev Biochem 21:249

121. Yonehara S, Yonehara-Takahashi M, Ishi A, Nagata S 1983 Different binding of human interferon $\alpha-1$ and $\alpha-2$ to common receptors on human and bovine cells. J Biol Chem 258:9046

122. Uze G, Luffally G, Gresser J 1990 Genetic transfer of a functional human interferon $\alpha$ receptor into mouse cells: cloning and expression of its cDNA. Cell 60:225

123. Aguet M 1991 Molecular cloning of interferon receptors: a short review. Br J Hematol 79[Suppl 1]:6

124. Nicos NA, Metcalf D 1991 Subunit promiscuity among hemopoietic growth factor receptors. Cell 67:1

125. Saito Y, Tada H, Sabe H, Honjo T 1991 Biochemical evidence for a third chain of the interleukin-2 receptor. J Biol Chem 266:22186
126. von Gabain A, Lundgren E, Ohlsson M, Holmgren E, Josephsson S, Alkan SA 1990 Three human interferon- $\alpha 2$ subvariants disclose structural and functional differences. Eur J Biochem 190:257

127. Hannigan GE, Gewert DR, Fish EN, Read SE, Williams RG 1983 Differential binding of human interferon- $\alpha$ subtypes to receptors on lymphoblastoid cells. Biochem Biophys Res Commun 110:537

128. Shafferman A, Velan B, Cohen S, Leitner M, Grosfeld H 1987 Specific residues within an amino-terminal domain of 35 residues of interferon $\alpha$ are responsible for recognition of the human interferon $\alpha$ cell receptor and for triggering biological effects. J Biol Chem 262:6227

129. Cheetham BF, McInnes B, Mantamadiotis T, Murray PJ, Alin P, Bourke P, Linnane AW, Tymms MJ 1991 Structure-function studies of human interferons- $\alpha$ : enhanced activity on human and murine cells. Antiviral Res 15:27

130. Redlich PN, Hoeprich PD, Colby CB, Grossberg SE 1991 Antibodies that neutralize human $\alpha$-interferon biologic activity recognize a linear epitope: analysis by synthetic peptide mapping. Proc Natl Acad Sci USA 88:4040

131. Kontsek P, Borecky L, Kontsekova E, Macikova I, Kolcunova A, Novak M, Krchnak V 1991 Mapping of two immunodominant structures on human interferon $\alpha 2 \mathrm{c}$ and their role in binding to cells. Mol Immunol 28:1289

132. Ruegg CL, Strand M 1990 Identification of a decapeptide region of human interferon- $\alpha$ with antiproliferative activity and homology to an immunosuppressive sequence of the retroviral transmembrane protein P15E. J Interferon Res 10:621

133. Pontzer DH, Ott TL, Bazer FW, Johnson HM 1990 Localization of an antiviral site on the pregnancy recognition hormone, ovine trophoblast protein-1. Proc Natl Acad Sci USA 87:5945

134. Williams BRG 1991 Transcriptional regulation of interferonstimulated genes. Eur J Biochem 200:1

135. Kerr IM, Stark GR 1991 Minireview: The control of interferoninducible gene expression. FEBS Lett 285:194

136. Pfeffer LM, Tan YH 1991 Do second messengers play a role in interferon signal transduction? Trends Biochem Sci 16:321

137. Hannigan GE, Williams BRG 1991 Signal transduction by interferon- $\alpha$ through arachidonic acid metabolism. Science 251:204

138. Bazer FW, Vallet JL, Ashworth CJ, Anthony RV, Roberts RM 1987 The role of ovine conceptus secretory proteins in the establishment of pregnancy. In: Leavitt WW (ed) Cell and Molecular Biology of the Uterus. Plenum Press, New York, pp 221-234

139. Mirando MA, Ott TL, Vallet JL, Davis M, Bazer FW 1990 Oxytocin-stimulated inositol phosphate turnover in endometrium of ewes in influenced by stage of the estrous cycle, pregnancy, and intrauterine infusion of ovine conceptus secretory proteins. Biol Reprod 42:98

140. Fowler AK, Reed CD, Giron DJ 1980 Identification of an interferon in murine placentas. Nature 286:266

141. Chard T 1989 Interferon in pregnancy. J Dev Physiol 11:271

142. Loke YW, King A 1990 Current topic: interferon and human placental development. Placenta 11:291

143. Harney JP, Bazer FW 1989 Effect of porcine conceptus secretory proteins on interestrous interval and uterine secretion of prostaglandins. Biol Reprod 41:277

144. Cross JC, Farin CE, Sharif SF, Roberts RM 1990 Characterization of the antiviral activity constitutively produced by murine conceptuses: absence of placental mRNAs for interferon $\alpha$ and $\beta$. Mol Reprod Dev 26:122

145. Cross JC, Roberts RM 1989 Porcine conceptuses secrete an interferon during the pre-attachment period of early pregnancy. Biol Reprod 40:1109

146. Mirando MA, Harney JP, Beers S, Pontzer $\mathrm{CH}$, Torres BA, Johnson HM, Bazer FW 1990 Onset of secretion of proteins with antiviral activity by pig conceptuses. J Reprod Fertil 88:197

147. Zouari K, Bezard J, Reinaud P, Guillomot M, Palmer E, Martal J 1991 Evidence for the presence of equine trophoblastic interferons during early pregnancy. J Interferon Res 11[Suppl 1]:S134 (Abstract)

148. Zouari K, Reinaud P, La Bonnardiere C, Martal J 1991 Uterine interferon during early pregnancy and pseudopregnancy in rabbits. J Interferon Res 11[Suppl 1]:S135 (Abstract) 
149. Ashworth CJ, Bazer FW 1989 Changes in ovine conceptus and endometrial function following asynchronous embryo transfer or administration of progesterone. Biol Reprod 40:425

150. Cross JC, Roberts RM 1991 Constitutive and trophoblast-specific expression of a class of bovine interferon genes. Proc Natl Acad Sci USA 88:3817

151. Roberts RM, Cross JC, Farin CE, Kramer K, Schalue-Francis F, Hansen TR 1990 Trophoblast interferons as antiluteolysins. In: Edwards RG (ed) Establishing a Successful Human Pregnancy. Serono Symposia Publications, Raven Press, New York, vol 66:257-268

152. Barlow DP, Randle BJ, Burke DC 1984 Interferon synthesis in the early post-implantation mouse embryo. Differentiation 27:229

153. Nieder GL, Jennes L 1990 Production of mouse placental lactogen-1 by trophoblast giant cells in utero and in vitro. Endocrinology 126:2809

154. Jacobsen H, Mestan J, Mittnacht S, Dieffenbach CW 1989 Beta interferon subtype I induction by tumor necrosis factor. Mol Cell Biol 9:3037

155. Mege D, Lefevre F, LaBonnardiere C 1991 The porcine family of interferon-omega: cloning, structural analysis and functional studies of five related genes. J Interferon Res 11:341

156. Burke DC 1986 Interferon and cell differentiation. Br J Cancer 53:301

157. Kohase M, Saito S, Iizuki E, Matsumura H, Kohno S 1983 Interferon production associated with the ageing of primary chick embryo cells is not caused by priming. J Gen Virol 64:2017

158. Martin GR 1980 Teratocarcinomas and mammalian embryogenesis. Science 209:768

159. Burke DC, Graham CF, Lehman JM 1978 Appearance of interferon inducibility and sensitivity during differentiation of murine teratocarcinoma cells in vitro. Cell 13:243

160. Wood JN, Hovanessian AG 1979 Interferon enhances 2-5A synthetase in embryonal carcinoma cells. Nature 282:74

161. Nilsen TW, Wood DL, Baglioni C 1980 Virus-specific effects of interferon in embryonal carcinoma cells. Nature 286:178

162. Ogunkolade W, Canivet M, Dochart F, Fourcade A, Chousterman S, Hovanessian A, Peries J 1987 Interferon inducibility and sensitivity of human teratocarcinoma-derived cell lines. J Interferon Res 7:245

163. Aguet M, Gresser I, Hovanessian AG, Bandu MT, Blanchard B, Blangy D 1981 Specific high-affinity binding of ${ }^{125}$ I-labeled mouse interferon to interferon resistant embryonal carcinoma cells in vitro. Virology 114:585

164. Zusman I, Engelhard D, Yaffe P, Ron A, Panet A, Ornoy A 1984 Effects of interferon and encephalomyocarditis virus on in vitro development of preimplantation mouse embryos with and without the zona pellucida. Teratology 29:405

165. Bowen RA 1988 Failure to induce an antiviral state in preimplantation bovine embryos treated with interferon. Theriogenology $30: 119$

166. Thomson MS, Bird RC, Stringfellow DA, Rossi CR, Lauerman LH 1989 Chemically-induced viral resistance in preimplantation bovine embryos. Theriogenology 31:267

167. Toth FD, Juhl C, Norskov-Laurtsen N, Mosberg Petersen P, Ebbesen P 1990 Interferon production by cultured human trophoblasts induced with double stranded polyribonucleotide. J Reprod Immunol 17:217

168. Haggarty A, Ponton A, Paterno GD, Daigneault L, Skup D 1988 An embryonic DNA-binding protein specific for a region of the human IFN- $\beta 1$ promoter. Nucleic Acids Res 16:10575

169. Coveney J, Scott G, King R, Burke DC 1984 Changes in the conformation of the interferon $\beta$ gene during differentiation and induction. Biochem Biophys Res Commun 121:290

170. Haggarty A, Camato R, Paterno G, Cohen L, Hiscott J, Skup D 1991 A developmentally regulated octamer-binding activity in embryonal carcinoma cells which represses $\alpha$-interferon expression. Cell Growth Differentiation 2:503

171. Scholer HR, Hatzopoulos AK, Balling R, Suzuki N, Gruss P 1989 Octamer-binding proteins confer transcriptional activity in early mouse embryogenesis. EMBO J 8:2551

172. Harada H, Willison K, Sakakibara J, Miyamoto M, Fujita T,
Taniguchi T 1990 Absence of the type I IFN system in EC cells: transcriptional activator (IRF-1) and repressor (IRF-2) genes are developmentally regulated. Cell 63:303

173. Tovey MG, Streuli M, Grener I, Guggenheim J, Blanchard B, Guymarho J, Vignaux F, Gigou M 1987 Interferon messenger RNA is produced constitutively in the organs of normal individuals. Proc Natl Acad Sci USA 84:5038

174. Bocci V, Paulesu L, Ricci MG 1985 The physiological interferon response. IV. Production of interferon by the perfused human placenta at term. Proc Soc Exp Biol Med 180:137

175. Khan NU-D, Pulford KAF, Farquharson MA, Howatson A, Stewart C, Jackson R, McNichol AM, Foulis AK 1989 The distribution of immunoreactive interferon- $\alpha$ in normal human tissues. Immunology 66:201

176. Sen GC, Lengyel P 1992 The interferon system. A bird's eye view of its biochemistry. J Biol Chem 267:5017

177. Cavalieri RL, Havell EA, Vilcek J, Pestka S 1977 Induction and decay of human fibroblast interferon mRNA. Proc Natl Acad Sci USA $74: 4415$

178. Raj NBK, Pitha PM 1983 Two levels of regulation of $\beta$-interferon gene expression in human cells. Proc Natl Acad Sci USA 80:3923

179. Whittemore LA, Maniatis T 1990 Postinduction turnoff of $\beta$ interferon gene expression. Mol Cell Biol 64:1329

180. Hansen TR, Cross JC, Farin CE, Imakawa K, Roberts RM 1991 Slowed transcription and rapid messenger RNA turnover contribute to a decline in synthesis of ovine trophoblast protein-1 during in vitro culture. Biol Reprod 45:94

181. Maniatis T, Whittemore LA, Du W, Fan CM, Keller A, Palombella V, Thanos D 1992 Positive and negative control of human interferon- $\beta$ gene expression. In: McKnight S, Yumamoto K (eds) Transcriptional Regulation. Cold Spring Harbor Laboratory, Cold Spring Harbor, NY, in press

182. Du W, Maniatis T 1992 An ATF/CREB binding site protein is required for virus induction of the human interferon $\beta$ gene. Proc Natl Acad Sci USA 89:2150

183. Lenardo MJ, Fan C-M, Maniatis T, Baltimore D 1989 The involvement of NF-kB in $\beta$-interferon gene regulation reveals its role as a widely inducible mediator of signal transduction. Cell $57: 287$

184. Miyamoto M, Fujita T, Kimura Y, Maruyama M, Harada H, Sudo $\mathrm{Y}$, Miyata T, Taniguchi T 1988 Regulated expression of a gene encoding a nuclear factor, IRF-1, that specifically binds to IFN- $\beta$ gene regulatory elements. Cell 54:903

185. Fujita T, Kimura Y, Miyamoto M, Barsoumian EC, Taniguchi T 1989 Induction of endogenous IFN- $\alpha$ and IFN- $\beta$ genes by a regulatory transcription factor, IRF-1. Nature 337:270

186. Fujita T, Sakakibara J, Sudo Y, Miyamoto M, Kimura Y, Taniguchi T 1989 Evidence for a nuclear factor(s) IRF-1 mediating induction and silencing properties to human IFN- $\beta$ gene regulatory elements. EMBO J 7:3397

187. Harada H, Fujita T, Miyamoto M, Kimura Y, Maruyama M, Furia A, Miyata T, Taniguchi T 1989 Structurally similar but functionally distinct factors, IRF-1 and IRF-2, bind the same regulatory elements of IFN and IFN-inducible gene. Cell 58:729

188. Reis LFL, Harada H, Wolchok JD, Taniguchi T, Vilcek J 1992 Critical role of a common transcription factor, IRF-1, in the regulation of IFN- $\alpha$ and IFN-inducible genes. EMBO J 11:185

189. Hiscott J Cantell K Weissmann C 1984 Differential expression of human interferon genes. Nucleic Acids Res 12:3727

190. Weidle U, Weissmann C 1983 The 5-flanking region of a human IFN- $\alpha$ gene mediates viral induction of transcription. Nature 303:442

191. MacDonald NJ, Kuhl D, Maguire D, Naf D, Gallant P, Goswamy A, Hug H, Bueler H, Chaturvedi M, de la Fuente J, Ruffner H, Meyer F, Weissman C 1990 Different pathways mediate virus inducibility of the human IFN- $\alpha_{\mathrm{I}}$ and IFN- $\beta$ genes. Cell 60:767

192. Leaman DW, Roberts RM 1992 Genes for the trophoblast interferons in sheep, goat and musk ox, and distribution of related genes among mammals. J Interferon Res 12:1

193. Whaley AE, Carroll RS, Imakawa K 1991 Cloning and analysis of a gene encoding ovine interferon $\alpha$-II. Gene 106:281

194. Shepard HM, Eaton D, Gray P, Maylor S, Hollingshead P, Goed- 
del D 1985 The human class II interferon- $\alpha$ family. In: Kirchner $\mathrm{H}$, Schellekens $\mathrm{H}$ (eds) The Biology of the Interferon System 1984. Elsevier, Amsterdam, pp 147-153

195. Adolf GR 1990 Monoclonal antibodies and emzyme immunoassays specific for human interferon (IFN) omega-1: evidence that IFN-omega 1 is a component of human leukocyte IFN. Virology 175:410

196. Heyman Y, Camous S, Fevre J, Meziou W, Martal J 1984 Maintenance of the corpus luteum after uterine transfer of trophoblastic vesicles to cyclic cows and ewes. J Reprod Fertil 70:533

197. Guillomot M, Michel C, Gaye P, Charlier N, Trojan J, Martal J 1990 Cellular localization of an embryonic interferon, ovine trophoblastin, and its mRNA in sheep embryos during early pregnancy. Biol Cell 68:205

198. Lifsey BJ, Baumbach GA, Godkin JD 1989 Isolation, characterization and immunocytochemical localization of bovine trophoblast protein-1. Biol Reprod 40:343

199. Xavier F, Guillomot M, Charlier M, Martal J, Gaye P 1991 Coexpression of the proto-oncogene FOS (c-fos) and an embryonic interferon (ovine trophoblastin) by sheep conceptuses during implantation. Biol Cell 73:27

200. Farin CE, Imakawa K, Roberts RM 1989 In situ localization of mRNA for the interferons, ovine trophoblast protein-1, during early embryonic development of the sheep. Mol Endocrinol 3:1099

201. Farin CE, Imakawa K, Hansen TR, McDonnell JJ, Murphy CN, Farin PW, Roberts RM 1990 Expression of trophoblastic interferon genes in sheep and cattle. Biol Reprod 43:210

202. Farin CE, Cross JC, Tindle NA, Murphy CN, Farin PW, Roberts RM 1991 Induction of trophoblastic interferon expression in ovine blastocysts after treatment with double-stranded RNA. J Interferon Res 11:151

203. Hansen PJ, Anthony RV, Bazer FW, Baumbach GA, Roberts RM 1985 In vitro synthesis and secretion of ovine trophoblast protein1 during the period of maternal recognition of pregnancy. Endocrinology 117:1424

204. Hansen TR, Imakawa K, Polites HG, Marotti KR, Anthony RV, Roberts RM 1988 Interferon RNA of embryonic origin is expressed transiently during early pregnancy in the ewe. J Biol Chem 263:12801

205. Wales RG, Cuneo GL 1989 Morphology and chemical analysis of the sheep conceptus from the 13th to the 19th day of pregnancy. J Reprod Fertil 1:31

206. Godkin JD, Lifsey BJ, Gillespie BE 1988 Characterization of bovine conceptus proteins produced during the peri- and postattachment periods of early pregnancy. Biol Reprod 38:703

207. Hernandez-Ledezma JJ, Sikes JD, Murphy CN, Watson AJ, Schultz GA, Roberts RM 1992 Expression of bovine trophoblast interferon in conceptuses derived by in vitro techniques. Biol Reprod, in press
208. Watson AJ, Hogan A, Hahnel A, Wiemer KE, Schultz GA 1991 Expression of growth factor ligand and receptor genes in the preimplantation bovine embryo. Mol Reprod Dev 31:87

209. Nephew KP, McClure KE, Ott TC, Dubois DH, Bazer FW, Pope WF 1991 Relationship between variation in conceptus development and differences in estrous cycle duration in ewes. Biol Reprod 44:536

210. Garrett JE, Geisert RD, Zavy MT, Morgan GL 1988 Evidence for maternal regulation of early conceptus growth and development in beef cattle. J Reprod Fertil 84:437

211. Ko Y, Lee CY, Ott TL, Davis MA, Simmen RCM, Bazer FW, Simmen FA 1991 Insulin-like growth factors in sheep uterine fluids: concentrations and relationship to ovine trophoblast protein-1 production during early pregnancy. Biol Reprod 45:135

212. Roberts RM, Cross JC, Leaman DW 1991 Cell-specific expression of the trophoblast interferons. J Interferon Res 11[Suppl 1]:S66 (Abstract)

213. Stewart HJ, McCann SHE, Flint APF 1990 Structure of an interferon- $\alpha 2$ gene expressed in the bovine conceptus early in gestation. J Mol Endocrinol 4:275

214. Delegeane AM, Ferland LH, Mellon PL 1987 Tissue-specific enhancer of the main glycoprotein hormone $\alpha$-subunit gene: dependence on cyclic AMP-inducible elements. Mol Cell Biol 7:3994

215. Walker WH, Fitzpatrick SL, Barrera-Saldana HA, ResendezPerez D, Saunders GF 1991 The human placental lactogen genes: structure, function, evolution and transcriptional regulation. Endocr Rev 12:316

216. Ringler GE, Strauss JF 1990 In vitro systems for the study of human placental endocrine function. Endocr Rev 11:105

217. Kessler MA, Schuler LA 1991 Structure of the bovine placental lactogen gene and alternative splicing of transcripts. DNA Cell Biol 10:93

218. Cross JC 1991 Trophoblast Proteins as Novel Type I Interferons. $\mathrm{PhD}$ thesis, University of Missouri-Columbia, Columbia, MO

219. Himmler A, Hauptmann R, Adolf GR, Swetly P 1987 Structure and expression in $E$. coli of canine interferon- $\alpha$ genes. J Interferon Res $7: 173$

220. Himmler A, Hauptmann R, Adolf GR, Swetly P 1986 Molecular cloning and expression in Escherichia coli of equine type 1 interferons. DNA 5:345

221. Van Soest E 1982 Nutritional Ecology of the Ruminant. O \& B Books, Inc., New York

222. Novacek MJ 1992 Mammalian phylogeny: shaking the tree. Nature $356: 121$

223. Ryan AM, Womack JE 1990 Somatic cell mapping and restriction fragment length analysis of bovine interferon gene families. $J$ Interferon Res 10[Suppl 1]:S37 (Abstract)

224. Rowson LEA, Moor RM 1966 Development of the sheep conceptus during the first fourteen days. J Anat 100:777 